\title{
Financial feasibility of end-user designed rainwater harvesting and greywater reuse systems for high water use households
}

\author{
Edgar Ricardo Oviedo-Ocaña ${ }^{1} \cdot$ Isabel Dominguez $^{1} \cdot \operatorname{Sarah~Ward~}^{2}$ (D) \\ Miryam Lizeth Rivera-Sanchez ${ }^{1}$. Julian Mauricio Zaraza-Peña ${ }^{1}$
}

Received: 11 October 2016 / Accepted: 28 February 2017 / Published online: 30 March 2017

(C) The Author(s) 2017. This article is published with open access at Springerlink.com

\begin{abstract}
Water availability pressures, competing end-uses and sewers at capacity are all drivers for change in urban water management. Rainwater harvesting (RWH) and greywater reuse (GWR) systems constitute alternatives to reduce drinking water usage and in the case of RWH, reduce roof runoff entering sewers. Despite the increasing popularity of installations in commercial buildings, RWH and GWR technologies at a household scale have proved less popular, across a range of global contexts. For systems designed from the top-down, this is often due to the lack of a favourable cost-benefit (where subsidies are unavailable), though few studies have focused on performing full capital and operational financial assessments, particularly in high water consumption households. Using a bottom-up design approach, based on a questionnaire survey with 35 households in a residential complex in Bucaramanga, Colombia, this article considers the initial financial feasibility of three RWH and GWR system configurations proposed for high water using households (equivalent to $>203$ L per capita per day). A full capital and operational financial assessment was performed at a more detailed level for the most viable design using historic rainfall data. For the selected configuration ('Alt 2'), the estimated potable water
\end{abstract}

Responsible editor: Philippe Garrigues

Sarah Ward

sarah.ward@exeter.ac.uk

1 Grupo de Investigación en Recursos Hídricos y Saneamiento Ambiental (GPH), Escuela de Ingeniería Civil, Facultad de Ingenierías Físico-Mecánicas, Universidad Industrial de Santander, Carrera 27 Calle 9, Bucaramanga, Colombia

2 Centre for Water Systems, College of Engineering, Mathematics and Physical Sciences, University of Exeter, Kay Building, North Park Road, Exeter EX4 4QF, UK saving was $44 \%$ (equivalent to $131 \mathrm{~m}^{3} /$ year) with a rate of return on investment of $6.5 \%$ and an estimated payback period of 23 years. As an initial end-user-driven design exercise, these results are promising and constitute a starting point for facilitating such approaches to urban water management at the household scale.

Keywords Alternative water supply systems $\cdot$ Colombia $\cdot$ End-user $\cdot$ Financial feasibility $\cdot$ Greywater reuse $\cdot$ Rainwater harvesting

\section{Introduction}

Increased pressure over water resources to meet the demands of growing populations is pushing supply systems to their limits (Couto et al. 2015). Aspects such as the reduction of water availability from surface and groundwater sources, continued population growth (e.g. an increase of 1.8 million people between 2005 and 2030 is projected) (Muthukumaran et al. 2011) and climate variability, which has increased episodes of drought, contribute to intensify concerns about water availability. These threats and trends make urgent the need to adapt water management and governance to current and changing social and environmental conditions (Domènech and Saurí 2011; Tian et al. 2012). In this context, water conservation and efficiency gain significance, involving both the controlled and efficient use of water resources and measures for wastewater reuse (Couto et al. 2015).

Residential water use represents the sector with lower water consumption worldwide (12\%), compared to agriculture (69\%) and industry (19\%) (FAO 2014). However, this sector is perhaps more responsive to the introduction of changes in water management that contribute to enhance the water efficiency of water-using everyday practices but not if 
oversimplified models of consumer behaviour are used (Hoolohan and Browne 2016). Water use in the residential sector depends, amongst other aspects, on cultural customs, economic development and water availability. However, general uses with higher consumption in developed or developing countries (i.e. Colombia, Brazil, Peru, USA and Germany) are toilet flushing, clothes washing, hand washing, personal hygiene (showers), food preparation and cleaning utensils (kitchen) and to a lesser extent house cleaning, own consumption (actual drinking) and garden irrigation (Cohim et al. 2009; Li et al. 2009; Mayer et al. 1999; Mourad et al. 2011; Seifert 2009; Silva et al. 2015; Suárez et al. 2006). This indicates that a high proportion of residential water uses do not require strictly drinking water quality - it is possible to use water with a lower quality for such uses. In Colombia, the amount of water for residential use that does not require drinking water quality could be approximately $71 \%$ (Suárez et al. 2006), being higher in households with high socioeconomic conditions (i.e. called strata 5 and 6), which are also characterised by higher water use levels (CRA 2001). At the opposite end of the demand spectrum, Sanches Fernandes et al. (2015) investigated rainwater harvesting $(\mathrm{RWH})$ systems for low-demand applications in the Portuguese context. Through examination of water-saving efficiency and tank sizing using the Ripple method, they identified the impact of drought events on tank sizing for two irrigation scenarios. Fifty-percent reductions in tank size were viable, resulting in positive impacts on cost and return periods without compromising efficiency or increasing probability of failure to supply.

Various options have been proposed to reduce water use in the residential sector including the development of low water consumption technology (Vieira et al. 2015); awareness programs aimed at water use efficiency; and implementation of policies, such as higher-cost tariffs (Sahin et al. 2015). One alternative increasingly considered is water reuse through decentralised systems (Matos et al. 2014). This alternative involves capturing water (e.g. greywater or rainwater) from generation sites (such as showers or basins or from roofs) and then treating and distributing it for non-potable water uses in the household (e.g. general washing and gardening purposes or toilet flushing) (Kujawa and Zeeman 2006; Lee et al. 2016). This approach mainly considers RWH and greywater reuse (GWR), which have the greatest potential as complementary alternative water sources or supply systems (AWSSs) due to their reduced pollution compared to other alternatives (Stec and Kordana 2015; WHO-ROEM 2006).

Technical and financial feasibility assessments are a key strategy to promote and make viable GWR and RWH at the household level. However, the majority of past studies have focused on public buildings (Neto et al. 2012), office buildings (Ward et al. 2012; Motawa and Carter 2013), universities (Roebuck and Ashley 2007), residential complexes (Gardels 2011) and communal systems for RWH (Gurung and Sharma
2014). Few studies have addressed individual households, such as those reported by Ghisi and Oliveira (2007) in Brazil and Domènech and Saurí (2011) and Morales-Pinzón et al. (2014) in Spain. The most recent study identified, by Melville-Shreeve et al. (2016), focused on multiple configurations of RWH systems for the household scale. Although the study used a multicriteria analysis, it only included capital RWH system costs (i.e. it did not include network, treatment or operation and maintenance costs or broader financial indicators) and did not consider GWR. In developing countries such as Colombia, limited information on the financial assessment of individual decentralised systems was identified.

In this research, the financial feasibility of implementing a system that allows for RWH and GWR to be used in strictly non-drinking water residential uses is evaluated, considering social, technical and building-related conditions linked to acceptability. The research is situated in a typical high water using household in Bucaramanga (Colombia). This paper evaluates indicators such as the internal rate of return (IRR), net present value (NPV) and payback period (PP), comparing the proposed system and the conventional alternative (i.e. without GWR and RWH).

\section{Materials and methods}

This section firstly outlines the study area in which the analysis is situated. Secondly, it describes the criteria used to design three AWSSs, including a questionnaire with residents in the study area. Thirdly, it identifies and explains the initial system screening criteria utilised to compare the three different systems, followed by detailed description of the selected AWSS focused on in subsequent analyses. Finally, it outlines the cost and financial criteria used to assess the financial feasibility of the selected AWSS.

\section{Study area}

The study system was situated in an urban household located in the metropolitan area of Bucaramanga (Colombia) and classified as socioeconomic stratum 6 (strata 1 and 6 represent the lowest and highest socioeconomic levels, respectively). The household had three floors, a roof comprising Spanish clay tiles $\left(101 \mathrm{~m}^{2}\right)$, a patio $\left(18 \mathrm{~m}^{2}\right)$, a garden $\left(21 \mathrm{~m}^{2}\right)$ and five bathrooms, across a total built area of $216 \mathrm{~m}^{2}$. The house was equipped with a hydro-pneumatic pump system located on the third floor (next to a previously used drinking water storage tank) to ensure the pressure for the bathroom located on this floor. The average rainfall in the study area was $1053 \mathrm{~mm} /$ year and the temperature was $25^{\circ} \mathrm{C}$ (IDEAM 2015). 


\section{Criteria for alternative RWH and GWR system designs}

In addition to standard design criteria, such as the sizing of the tank, features affecting end-user acceptability and water quality should also be considered at the design stage. In this study, the focus was on social acceptability in relation to source water and willingness to undertake maintenance activity and water quality with regard to consideration of including a treatment system.

\section{User acceptability}

A questionnaire was developed to determine the types of criteria that may be important to householders in the design of a RWH or GWR system. The questionnaire had 14 questions that explored issues such as (i) average per capita water consumption, (ii) the device users would be willing to connect to an AWSS, (iii) participants' willingness to undertake operation and maintenance activities of an eventual AWSS and (iv) the range of additional investment that users would be willing to pay for such a system.

Using the questionnaire, a survey was conducted in a residential complex of 115 households, belonging to socioeconomic stratum 6 and located in the metropolitan area of Bucaramanga. A random selection of households was not feasible because $30 \%$ of the households were empty at the time of the survey. In addition, in a further $40 \%$, the householders were not willing to participate in the survey. Therefore, $100 \%$ of the households available and willing to participate at the time of the fieldwork were surveyed, representing $30 \%$ of the households in the residential complex (i.e. 35 households), which is an acceptable cooperation rate as recommended by Robson (2002).

From the water service bills provided by the residents who took part in the household survey ( 35 households), an average water consumption of $203 \mathrm{~L}$ per capita per day (lpcd) ( $\pm 84 \mathrm{lpcd})$ was estimated. This value was higher than the average value reported for the country, which for high socioeconomic strata (i.e. 5 and 6) is 170 lpcd (CRA 2001). However, the case study is located in a region with warm temperatures $\left(25^{\circ}\right)$, which in addition to the high socioeconomic stratum could contribute to the observed water consumption levels being higher than the country average for the correspondent socioeconomic strata.

It was identified that 97 and $86 \%$ of participants were willing to use AWSS, such as rainwater and greywater, respectively. These results were similar to those obtained for GWR in Brazil (De Araujo Batista et al. 2015) and Oman (Prathapar et al. 2005), where 83 and $84 \%$, respectively, expressed this willingness. However, there was greater acceptance for RWH compared with GWR due to hygiene concerns when greywater is used (100\% of participants), as found by De Araujo Batista et al. (2015) in the city of Campinhas (Brazil).
Participants expressed greater willingness to use GWR and RWH in areas of the home including toilets, patio, garden, laundry and washing machine (Fig. 1), coinciding with the accepted uses in countries such as South Africa (Dobrowksy et al. 2014), the UK (Ward et al. 2013) and Oman (Prathapar et al. 2005). Based on these results, it was decided to include these end-uses as those proposed to be connected to the designed AWSS due to the demonstrated acceptability.

Regarding the willingness of users to perform reactive maintenance on the AWSS, $94 \%$ of participants indicated that they would be willing to carry out this type of activity once every 2 weeks, $83 \%$ once a week, $34 \%$ twice a week and only $9 \%$ daily. Concerning preventive maintenance, $94 \%$ of participants suggested that they would perform this maintenance annually, $83 \%$ every 6 months and $37 \%$ monthly. Taking into account the availability of householders to perform maintenance tasks is an integral element in designing the system and is of importance as it is one of the factors affecting the acceptance of such systems, as identified in the UK by Ward et al. (2013).

In relation to the willingness to pay for implementing RWH and GWR systems in a new household, participants would be willing to increase the initial investment cost compared to that of a conventional household as follows: (a) less than 2300 USD, 94\% of participants; (b) between 2300 and 4900 USD, 54\%; and (c) more than 4900 USD, 14\%. These findings excluded the consideration of some GWR proposals in this study, for instance, prefabricated or proprietary off-the-shelf devices that met drinking water quality standards, whose costs for 2015 were 15,800 USD and which are available from Latin American providers (Agua2use 2015).

\section{Water quality for RWH and GWR systems}

A review of literature on the physicochemical and microbiological parameters in RWH and GWR systems was conducted in order to incorporate the information into the selection and design of the treatment system, primarily relating to concerns raised in the questionnaire results. The review focused on parameters such as $\mathrm{pH}$, total suspended solids (TSSs), turbidity, heavy metals, total and faecal coliforms. The search was conducted in specialised journals from databases such as Scopus ${ }^{\circledR}$, ScienceDirect ${ }^{\circledR}$, CRCnetdatabase ${ }^{\circledR}$, EBSCO ${ }^{\circledR}$ and Springer ${ }^{\circledR}$.

According to research conducted in Israel (Friedler 2004), Portugal (Matos et al. 2015), UK (ETH 2009) and other countries (Ghaitidak and Yadav 2013), it was identified that the shower is the sanitary device with better physicochemical characteristics for GWR, and therefore, it was selected as the source of greywater in this study.

Harvested rainwater quality, however, depends on the number of dry days before precipitation (Kwaadsteniet et al. 2013); roof material (Lee et al. 2012); building design features (Ward et al. 2010); and external contamination from roofs, canals and air pollution (Mendez et al. 2011), which can 


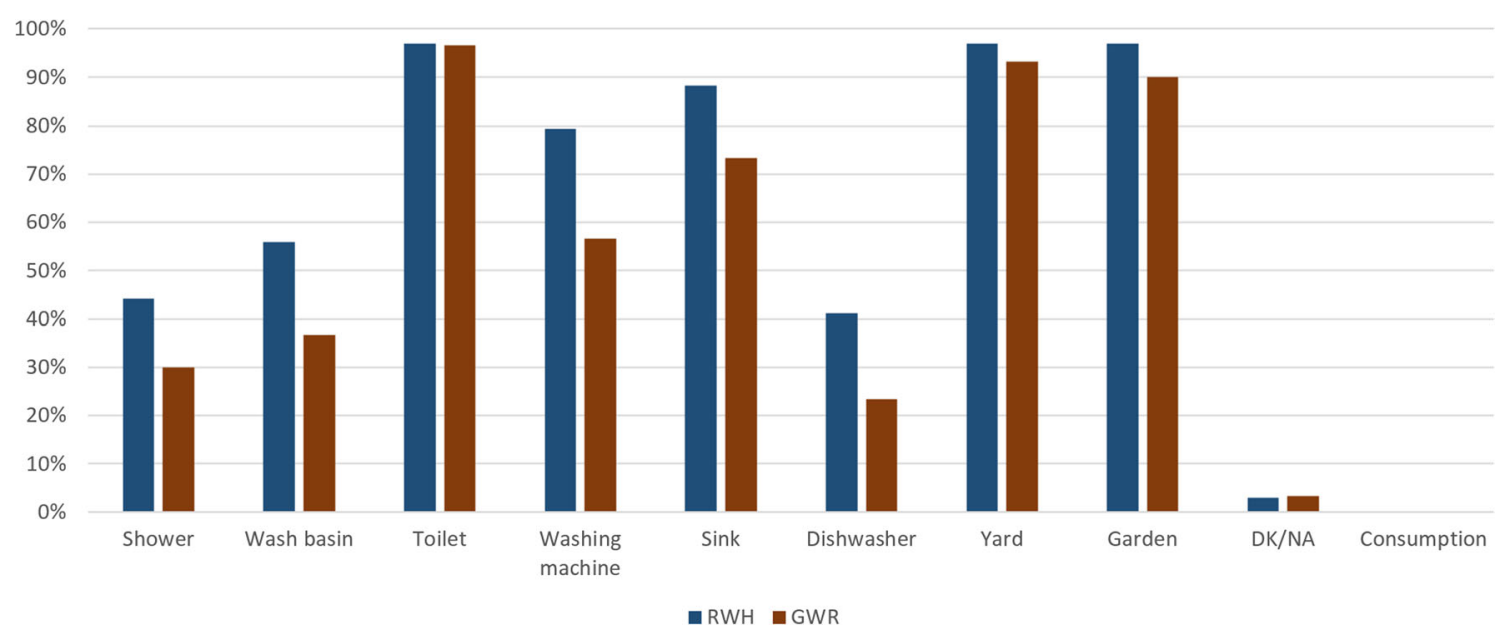

Fig. 1 End-uses in which participants were willing to utilise rainwater harvesting or greywater reuse

generate significant concentrations of ions (ammonium, nitrate and sulphate), especially in highly urbanised areas (Sánchez et al. 2015). Table 1 compiles the results from nine investigations about rainwater quality in urban environments in different countries, with monthly average rainfall greater than $60 \mathrm{~mm}$, and compares them against three standards for reuse in potable and non-potable water uses. According to the information reported in Table 1, national quality standards for the use of rainwater in non-potable purposes in some countries are $\mathrm{pH}$, TSS, turbidity, CT and Escherichia coli. Additionally, the studies that have evaluated the quality of harvested rainwater in different contexts indicate that generally, the parameters associated to this water source exceed the limit values set by those standards. Consequently, consideration of treatment processes and decisions regarding whether or not to include them may be based on site factors, human factors or, less so, on empirical data collected at a proposed site. The authors could not identify any water quality data for the specific case study site in Colombia focused on in the present research; therefore, this brief review suggests that the inclusion of contamination prevention or treatment systems for RWH and GWR should be considered at the design stage, in order to minimise contamination mainly associated with TSS, turbidity and total and faecal coliforms.

\section{Formulation and assessment of alternative system designs for RWH and GWR}

\section{Proposed alternatives}

Three alternatives (Alt 1, Alt 2 and Alt 3), summarised in Fig. 2, for the GWR and RWH systems were initially proposed trying to balance end-user preferences and water availability. For this, a factor that weights two features was computed: (i) users' preferences concerning end-uses for the alternative sources (rainwater and greywater), captured through the household survey (users' acceptability (u.a.)), and (ii) water demand for each end-use. The weight of the features was defined based on the authors' experience, where the u.a. had greater weight $(0.8)$ than end-use water demand $(0.2)$, as it is well documented that acceptability can limit utilisation of alternative water supplies rather than availability. Table 2 summarises the results for the calculation of this factor (the potential end-use factor (p.eu.f)).

Using results of the potential end-use factor for rainwater (p.eu.f.rw) and greywater (p.eu.f.gw), Alt 1 consisted of harvested rainwater collection, treatment and storage for use in toilets ( 0.82 p.eu.f.rw ), external tap ( 0.79 p.eu.f.rw) and internal taps ( 0.78 p.eu.f.rw) (i.e. the three higher p.eu.f.rw). Alt 2 consisted of harvested rainwater for use in washing machines ( 0.67 p.eu.f.rw), sinks ( 0.72 p.eu.f.rw), internal taps ( 0.79 p.eu.f.rw) and external taps $(0.78$ p.eu.f.rw) and greywater from showers for use in toilets (0.94 p.eu.f.gw) (i.e. the five higher p.eu.f.gw). Alt 3 consisted of harvested rainwater for use in washing machines (0.67 p.eu.f.rw), sinks ( 0.72 p.eu.f.rw) and internal taps ( 0.79 p.eu.f.rw) and greywater from showers for use in external taps (0.88 p.eu.f.gw). Since Colombia lacks regulation of AWSS, usage in sinks is considered as a non-drinking water residential use, despite the possibility that water from sink taps may be ingested.

For each of these alternatives, given in the following sections, an initial analysis of the savings in water and energy demand was made. The alternative that offered greater water savings and lower energy costs was assessed further based on additional criteria such as network configuration, which is described in the "Design of RWH and GWR system alternative 2" section.

\section{Dimensioning of storage tanks}

\section{Rainwater}

The method proposed in this study consisted of assessing five options for the tank capacity $\left(T_{1} 1 \mathrm{~m}^{3}, T_{2} 2 \mathrm{~m}^{3}, T_{3} 3 \mathrm{~m}^{3}, T_{4}\right.$ 


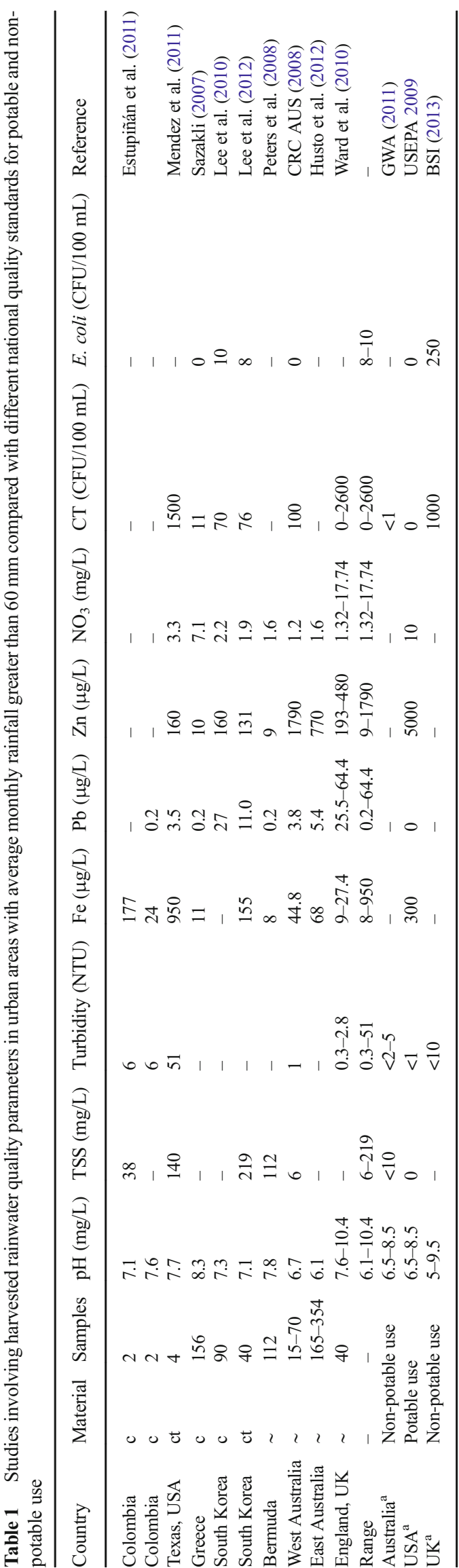

$4 \mathrm{~m}^{3}, T_{5} 5 \mathrm{~m}^{3}$ ), considering the commercially available tanks in Colombia and the supply from harvested rainwater that could be available, established from rainfall records for a 15year period (1985-2001). Daily rainfall records were obtained from a meteorological station located $2 \mathrm{~km}$ from the study area and operated by the Instituto de Hidrología, Meteorología y Estudios Ambientales from Colombia (IDEAM). The estimation was conducted as follows:

i) The daily rainfall needed to fill each tank size $\left(P_{T i}\right)$ was estimated with the available roof area $(A)\left(101 \mathrm{~m}^{2}\right)$. As result, $P_{T i}$ values for each tank were $P_{T 1} 9.90 \mathrm{~mm}, P_{T 2}$ $18.80 \mathrm{~mm}, P_{T 3} 29.70 \mathrm{~mm}, P_{T 4} 39.60 \mathrm{~mm}$ and $P_{T 5}$ $49.51 \mathrm{~mm}$.

ii) The volume of harvested rainwater was estimated for each week and each tank size considering

- Rainfall episodes each week where precipitation was lower than $P_{T i}$.

- Rainfall episodes each week where precipitation was equal or higher than $P_{T i}$.

The rainfall episodes each week where precipitation was lower than $P_{T i}$ were added to establish a cumulative value $(L)$. For the rainfall episodes each week, where precipitation was equal or higher than $P_{T i}$, the number of days this situation occurred was determined each week $(F)$. It was considered that overflows during these days would enter the drainage system (e.g. for $T_{1}, 10.30 \mathrm{~mm}$ rain would produce an overflow of $10.30-9.90 \mathrm{~mm}=0.40 \mathrm{~mm}$ ). Equation 1 indicates the formula used to establish the volume of harvested rainwater for each month and each tank size option,

$V_{i, j-T i}=\left[\left(\sum L \times C\right)+\left(F \times P_{T i}\right)\right] \times \frac{A}{1000 \mathrm{~mm} / \mathrm{m}^{3}}$

where $V_{i, j-T i}$ is the water volume cumulated in week $i$, from year $j$, for a storage tank of size $i\left(\mathrm{~m}^{3}\right) ; L$ is the rainfall values in week $i$, for which daily rainfall was less than $P_{T i}(\mathrm{~mm}) ; C$ is the runoff coefficient for the roof area (in this case, 0.9 as recommended for clay tiles; UNATSABAR 2001); $F$ is the number of days in week $i$, with rainfall higher than $P_{T i} ; P_{T i}$ is the rainfall needed to fill the storage tank $i(\mathrm{~mm})$; and $A$ is the roof area $\left(\mathrm{m}^{2}\right)$ (in this case, $101 \mathrm{~m}^{2}$ ).

The average weekly volume of rainwater harvested for each tank of the analysed sizes was calculated with the values established for each year obtained as shown in Eq. 1 (values for 15 years). The annual supply of harvested rainwater was determined as the total of the average water volumes calculated for each week of the year (see Table 3). Finally, water volumes from the rainwater harvested during a year in tanks of consecutive sizes were compared as shown in Table 3.

Although a bespoke methodology was used to determine the size of the tank, the works of Sanches Fernandes et al. (2015), 


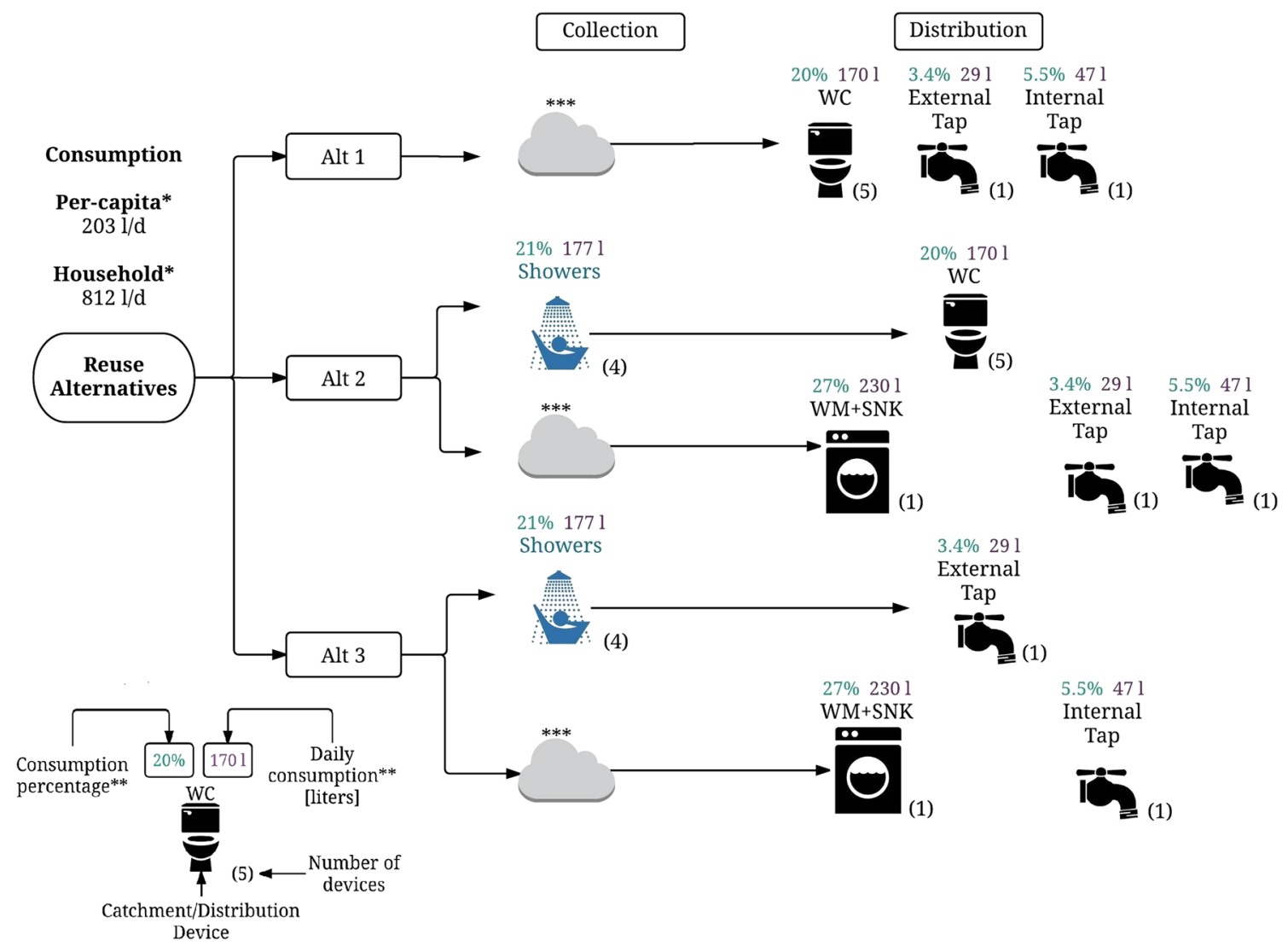

Fig. 2 Three proposed alternative rainwater harvesting and greywater reuse systems detailing water sources and potential end-uses

Santos and Taveira-Pinto (2013), Ghisi (2001) and Fewkes and Butler (2000) were taken into account to conduct the sizing.

The difference in water volumes that could be stored comparing tanks of consecutive sizes 1,2 and $3 \mathrm{~m}^{3}$ was considerable, and from the tank of $4 \mathrm{~m}^{3}$, the savings differential reduced. For this reason, tanks $T_{2}$ and $T_{3}$ (i.e. 2 and $3 \mathrm{~m}^{3}$, respectively) were considered as potential options to implement. The analysis of supply and demand is presented in the "Initial assessment of alternatives" section.

Table 2 Potential end-use factor

\begin{tabular}{lllllllll}
\hline Factors & sh & wb & to & wm & snk & dw & it $^{\mathrm{d}}$ & et $^{\mathrm{d}}$ \\
\hline u.a.rw $^{\mathrm{a}}$ & 0.44 & 0.56 & 0.97 & 0.79 & 0.88 & 0.41 & 0.97 & 0.97 \\
u.a.gw $^{\mathrm{a}}$ & 0.30 & 0.37 & 0.97 & 0.57 & 0.73 & 0.23 & 0.93 & 0.90 \\
Consumption $^{\mathrm{b}}$ & 0.21 & 0.04 & 0.20 & 0.17 & 0.10 & 0.16 & 0.06 & 0.03 \\
p.eu.f.rw $^{\mathrm{c}}$ & 0.39 & 0.46 & 0.82 & 0.67 & 0.72 & 0.36 & 0.79 & 0.78 \\
p.eu.f.gw $^{\mathrm{c}}$ & 0.32 & 0.39 & 0.94 & 0.59 & 0.73 & 0.26 & 0.90 & 0.88 \\
\hline
\end{tabular}

${ }^{a}$ u.a.() user acceptability scaled from 0 to 1 for rainwater (rw) and greywater (gw), based on survey results

${ }^{\mathrm{b}}$ Indicated as percentage of total household consumption, based on CRA (2001)

${ }^{c}$ p.eu.f.() potential end-use factor $=[$ u.a. ()$\times 0.8]+[$ consumption $\times 0.2]$

$\mathrm{d}$ (sh) shower, (wb) wash basin, (to) toilet, (wm) washing machine, sink (snk), dishwashing (dw), (it) interior tap, (et) external tap (i.e. garden). End-uses it and et are for cleaning and irrigation only

\section{Greywater}

Tank dimensioning for the GWR system considered the use frequency of the devices that contributed to greywater supply and demand (Fig. 2). As greywater cannot remain in the tank for more than $48 \mathrm{~h}$ (Al-Jayyousi 2003; March and Gual 2009) due to the exponential growth of microorganisms, the volume of storage required ( $\left.V_{\text {required }}\right)$ must be equal to the volume of demand in $48 \mathrm{~h}$ ( $V_{\text {demand }}$ in a cycle of use) to ensure (i) water supply and (ii) the renewal of water.

In Alt 2, water supply and water demand were considered at a daily frequency. Thus, the required storage was the smallest value between demand (169 L/day) and supply (177 L/day) (Eq. 2).

$V_{\text {required }}=\left(V_{\text {daily offer }}, \quad V_{\text {daily demand }}\right)$

For Alt 3, the household survey indicated that the use of the garden tap was once every 3 days (2.5 times per week), for a demand of $83 \mathrm{~L} /$ use. The water used in showers (daily use) provided a volume of $177 \mathrm{~L} /$ day. Thus, the required volume of the tank was $83 \mathrm{~L}$, but the selected tank was 300 -L capacity due to the sizes available commercially and considering the installation of a drain when the water level corresponds to a volume of $90 \mathrm{~L}$ to ensure the periodic renewal of the stored greywater. 
Table 3 Annual rainwater available for various tank sizes

\begin{tabular}{|c|c|c|c|c|c|c|}
\hline \multirow[t]{2}{*}{ Week } & \multirow[t]{2}{*}{ Units } & \multicolumn{5}{|c|}{ Storage tank size } \\
\hline & & $T_{1}$ & $T_{2}$ & $T_{3}$ & $T_{4}$ & $T_{5}$ \\
\hline 1 & $\mathrm{~m}^{3} /$ week & 0.83 & 1.00 & 1.11 & 1.17 & 1.21 \\
\hline 2 & $\mathrm{~m}^{3} /$ week & 0.79 & 1.16 & 1.30 & 1.36 & 1.40 \\
\hline 3 & $\mathrm{~m}^{3} /$ week & 0.60 & 0.75 & 0.82 & 0.86 & 0.86 \\
\hline 4 & $\mathrm{~m}^{3} /$ week & 0.58 & 0.74 & 0.84 & 0.86 & 0.86 \\
\hline 5 & $\mathrm{~m}^{3} /$ week & 0.88 & 1.24 & 1.39 & 1.46 & 1.48 \\
\hline 6 & $\mathrm{~m}^{3} /$ week & 1.10 & 1.46 & 1.59 & 1.59 & 1.59 \\
\hline 7 & $\mathrm{~m}^{3} /$ week & 0.41 & 0.47 & 0.53 & 0.53 & 0.53 \\
\hline 8 & $\mathrm{~m}^{3} /$ week & 1.01 & 1.51 & 1.86 & 2.10 & 2.22 \\
\hline 9 & $\mathrm{~m}^{3} /$ week & 1.21 & 1.33 & 1.38 & 1.38 & 1.38 \\
\hline 10 & $\mathrm{~m}^{3} /$ week & 0.89 & 1.22 & 1.45 & 1.59 & 1.61 \\
\hline 11 & $\mathrm{~m}^{3} /$ week & 1.23 & 1.51 & 1.65 & 1.74 & 1.74 \\
\hline 12 & $\mathrm{~m}^{3} /$ week & 1.22 & 1.51 & 1.62 & 1.62 & 1.62 \\
\hline 13 & $\mathrm{~m}^{3} /$ week & 1.64 & 2.40 & 2.84 & 3.12 & 3.24 \\
\hline 14 & $\mathrm{~m}^{3} /$ week & 0.95 & 1.41 & 1.61 & 1.71 & 1.77 \\
\hline 15 & $\mathrm{~m}^{3} /$ week & 0.86 & 1.24 & 1.35 & 1.40 & 1.40 \\
\hline 16 & $\mathrm{~m}^{3} /$ week & 1.56 & 2.04 & 2.28 & 2.44 & 2.54 \\
\hline 17 & $\mathrm{~m}^{3} /$ week & 1.52 & 2.03 & 2.22 & 2.35 & 2.40 \\
\hline 18 & $\mathrm{~m}^{3} /$ week & 1.37 & 1.73 & 1.81 & 1.87 & 1.93 \\
\hline 19 & $\mathrm{~m}^{3} /$ week & 1.21 & 1.56 & 1.75 & 1.81 & 1.85 \\
\hline 20 & $\mathrm{~m}^{3} /$ week & 0.95 & 1.10 & 1.23 & 1.29 & 1.36 \\
\hline 21 & $\mathrm{~m}^{3} /$ week & 2.10 & 2.66 & 2.84 & 2.94 & 2.97 \\
\hline 22 & $\mathrm{~m}^{3} /$ week & 1.30 & 1.68 & 1.94 & 2.08 & 2.20 \\
\hline 23 & $\mathrm{~m}^{3} /$ week & 1.00 & 1.26 & 1.37 & 1.42 & 1.42 \\
\hline 24 & $\mathrm{~m}^{3} /$ week & 1.08 & 1.37 & 1.49 & 1.52 & 1.52 \\
\hline 25 & $\mathrm{~m}^{3} /$ week & 1.18 & 1.28 & 1.28 & 1.28 & 1.28 \\
\hline 26 & $\mathrm{~m}^{3} /$ week & 1.04 & 1.23 & 1.26 & 1.26 & 1.26 \\
\hline 27 & $\mathrm{~m}^{3} /$ week & 1.53 & 1.74 & 1.83 & 1.89 & 1.95 \\
\hline 28 & $\mathrm{~m}^{3} /$ week & 1.30 & 1.64 & 1.69 & 1.69 & 1.69 \\
\hline 29 & $\mathrm{~m}^{3} /$ week & 1.48 & 1.88 & 2.07 & 2.25 & 2.36 \\
\hline 30 & $\mathrm{~m}^{3} /$ week & 1.36 & 1.87 & 2.06 & 2.13 & 2.13 \\
\hline 31 & $\mathrm{~m}^{3} /$ week & 1.03 & 1.21 & 1.34 & 1.44 & 1.44 \\
\hline 32 & $\mathrm{~m}^{3} /$ week & 1.21 & 1.37 & 1.43 & 1.43 & 1.43 \\
\hline 33 & $\mathrm{~m}^{3} /$ week & 1.07 & 1.33 & 1.48 & 1.61 & 1.73 \\
\hline 34 & $\mathrm{~m}^{3} /$ week & 0.94 & 1.00 & 1.00 & 1.00 & 1.00 \\
\hline 35 & $\mathrm{~m}^{3} /$ week & 1.60 & 1.93 & 2.15 & 2.22 & 2.28 \\
\hline 36 & $\mathrm{~m}^{3} /$ week & 1.38 & 1.62 & 1.69 & 1.69 & 1.69 \\
\hline 37 & $\mathrm{~m}^{3} /$ week & 1.67 & 1.99 & 2.09 & 2.15 & 2.22 \\
\hline 38 & $\mathrm{~m}^{3} /$ week & 1.56 & 2.09 & 2.38 & 2.50 & 2.56 \\
\hline 39 & $\mathrm{~m}^{3} /$ week & 1.55 & 1.91 & 2.00 & 2.06 & 2.12 \\
\hline 40 & $\mathrm{~m}^{3} /$ week & 1.56 & 2.08 & 2.34 & 2.48 & 2.56 \\
\hline 41 & $\mathrm{~m}^{3} /$ week & 1.99 & 2.66 & 2.77 & 2.83 & 2.85 \\
\hline 42 & $\mathrm{~m}^{3} /$ week & 1.43 & 1.90 & 2.21 & 2.34 & 2.46 \\
\hline 43 & $\mathrm{~m}^{3} /$ week & 1.20 & 1.56 & 1.82 & 2.00 & 2.12 \\
\hline 44 & $\mathrm{~m}^{3} /$ week & 1.18 & 1.44 & 1.67 & 1.80 & 1.89 \\
\hline 45 & $\mathrm{~m}^{3} /$ week & 1.35 & 1.79 & 2.04 & 2.23 & 2.32 \\
\hline 46 & $\mathrm{~m}^{3} /$ week & 1.04 & 1.28 & 1.32 & 1.32 & 1.32 \\
\hline 47 & $\mathrm{~m}^{3} /$ week & 1.42 & 1.80 & 1.93 & 1.97 & 1.97 \\
\hline
\end{tabular}

Table 3 (continued)

\begin{tabular}{lllllll}
\hline \multirow{2}{*}{ Week } & \multirow{2}{*}{ Units } & \multicolumn{5}{l}{ Storage tank size } \\
\cline { 3 - 7 } & & $T_{1}$ & $T_{2}$ & $T_{3}$ & $T_{4}$ & $T_{5}$ \\
\hline 48 & $\mathrm{~m}^{3} /$ week & 0.92 & 1.16 & 1.31 & 1.44 & 1.54 \\
49 & $\mathrm{~m}^{3} /$ week & 0.96 & 1.13 & 1.14 & 1.14 & 1.14 \\
50 & $\mathrm{~m}^{3} /$ week & 0.70 & 0.85 & 0.96 & 0.96 & 0.96 \\
51 & $\mathrm{~m}^{3} /$ week & 0.32 & 0.40 & 0.44 & 0.44 & 0.44 \\
52 & $\mathrm{~m}^{3} /$ week & 0.50 & 0.56 & 0.56 & 0.56 & 0.56 \\
Total year & $\mathrm{m}^{3} /$ year & 60.78 & 77.11 & 84.53 & 88.31 & 90.37 \\
Difference & $\mathrm{m}^{3}$ & - & 16.33 & 7.42 & 3.78 & 2.06 \\
Increase & $\%$ & - & 26.86 & 9.62 & 4.47 & 2.33 \\
\hline
\end{tabular}

\section{Initial assessment of alternatives}

Using the outline alternative system configurations and tank sizes, drinking water savings and energy consumption were assessed in order to select one of the three alternative system configurations for a full financial analysis. As the three configurations had similar social acceptability and technical requirements, it was decided to focus on complete evaluation of the configuration with the greater savings and lower-energy implications.

\section{Drinking water savings}

Drinking water savings due to RWH were computed based on the difference between weekly supply and demand, adding accumulations from previous week (if generated). Supply was considered variable and estimated as explained in the "Dimensioning of storage tanks" section, whilst demand was assumed constant. The procedure was as follows:

i) Demand was established considering the proportion of water consumed by each end-use (CRA 2001), 19.9\% toilets, $17.0 \%$ washing machine, $10.2 \%$ sink, $3.4 \%$ external tap and $5.5 \%$ internal tap. The water quantity for each of the proposed alternatives, considering the total water consumption in the household $(847.51 \mathrm{~L} /$ day $)$ and the consumption in the selected end-uses, was $244 \mathrm{~L} /$ day (Alt 1), 259 L/day (Alt 2) and 277 L/day (Alt 3).

ii) Demand was established for each week of the year, for each alternative, 1709 L/week (Alt 1), 2141 L/week (Alt 2) and $1939 \mathrm{~L} /$ week (Alt 3).

iii) Weekly supply was estimated for each week, based on the calculations described in the "Dimensioning of storage tanks" section (according to Table 3).

iv) The difference between supply and demand was calculated for each week of the year, in each year between 1986 and 2001. 
v) When the difference between supply and demand was positive, the exceeding volume was added to the supply for the following week, unless it exceeded the tank volume, in which case it was allocated as overflow to drainage. When the difference between supply and demand was negative, supply was considered insufficient for the demand in the tank option $\left(T_{i}\right)$ and alternative assessed (Alt ${ }_{X}$.

vi) Drinking water savings due to RW were established considering the higher value between supply and demand for each week. This was calculated for each year and each alternative. It was considered that if at the end of a week there was rainwater surplus, only an amount equal to or less to the tank volume could be stored.

vii) Drinking water savings were estimated for each year (1986 to 2001), and finally, an average of the annual water savings of each alternative was calculated (see Table 4).

Table 4 includes the annual volume of drinking water saved and the associated costs due to the storage tanks of $2 \mathrm{~m}^{3}\left(T_{2}\right)$ and $3 \mathrm{~m}^{3}\left(T_{3}\right)$ for Alt 1 , Alt 2 and Alt 3 . System efficiency was estimated considering the annual water savings obtained from each alternative and the annual demand of the system. The following results were obtained: Alt $177.2 \%\left(T_{2}\right)$ and $78.2 \%\left(T_{3}\right)$, Alt $263.4 \%\left(T_{2}\right)$ and $67.6 \%\left(T_{3}\right)$ and Alt $368.1 \%\left(T_{2}\right)$ and $72.4 \%\left(T_{3}\right)$.

The difference in volume of drinking water saved by using a tank of $3 \mathrm{~m}^{3}$ or a tank of $2 \mathrm{~m}^{3}$ (i.e. between 0.90 and $4.72 \mathrm{~m}^{3}$ ) was considered low compared to the higher acquisition, energy and construction costs associated with the tank of $3 \mathrm{~m}^{3}$. Therefore, it was decided to use a RWH system with a storage tank of $2 \mathrm{~m}^{3}$ in the final design configuration.

In the case of the GWR system, supply and demand were considered constant during the year. Therefore, the drinking water saving in this system was the lower value between supply and demand; therefore, the volume of drinking water saved during a year due to GWR in each alternative was (i) $0.00 \mathrm{~m}^{3}$, (ii) $60.72 \mathrm{~m}^{3}$ and (iii) $10.37 \mathrm{~m}^{3}$.

\section{Energy consumption}

The energy consumption of the RWH and GWR system was due to the pumps required to deliver stored water into the pipe network of the house. To establish this consumption, the power of the pump $\left(P_{\text {pump }}\right)$ and operating time $(t)$ required estimation. $t$ depended on the volume of water to be pumped (vol) and pump flow
Table 4 Drinking water annual savings (volume and costs) for three Alt RWH system configurations

\begin{tabular}{|c|c|c|c|c|c|c|c|}
\hline \multirow[t]{2}{*}{ Week } & \multirow[t]{2}{*}{ Unit } & \multicolumn{2}{|c|}{ Alt 1} & \multicolumn{2}{|c|}{ Alt 2} & \multicolumn{2}{|c|}{ Alt 3} \\
\hline & & $T_{2}$ & $T_{3}$ & $T_{2}$ & $T_{3}$ & $T_{2}$ & $T_{3}$ \\
\hline 1 & $\mathrm{~m}^{3} /$ week & 0.8 & 0.8 & 0.9 & 0.9 & 0.9 & 0.9 \\
\hline 2 & $\mathrm{~m}^{3} /$ week & 0.8 & 0.8 & 0.9 & 0.9 & 0.9 & 0.9 \\
\hline 3 & $\mathrm{~m}^{3} /$ week & 0.9 & 0.9 & 0.9 & 1.0 & 0.9 & 0.9 \\
\hline 4 & $\mathrm{~m}^{3} /$ week & 0.6 & 0.8 & 0.6 & 0.8 & 0.6 & 0.8 \\
\hline 5 & $\mathrm{~m}^{3} /$ week & 1.0 & 1.0 & 1.1 & 1.1 & 1.1 & 1.1 \\
\hline 6 & $\mathrm{~m}^{3} /$ week & 1.1 & 1.1 & 1.2 & 1.3 & 1.2 & 1.2 \\
\hline 7 & $\mathrm{~m}^{3} /$ week & 0.9 & 0.9 & 0.8 & 0.9 & 0.8 & 0.9 \\
\hline 8 & $\mathrm{~m}^{3} /$ week & 0.9 & 1.0 & 1.0 & 1.0 & 0.9 & 1.0 \\
\hline 9 & $\mathrm{~m}^{3} /$ week & 1.2 & 1.2 & 1.4 & 1.4 & 1.3 & 1.3 \\
\hline 10 & $\mathrm{~m}^{3} /$ week & 1.2 & 1.2 & 1.2 & 1.3 & 1.2 & 1.3 \\
\hline 11 & $\mathrm{~m}^{3} /$ week & 1.5 & 1.5 & 1.5 & 1.7 & 1.5 & 1.6 \\
\hline 12 & $\mathrm{~m}^{3} /$ week & 1.1 & 1.3 & 1.2 & 1.3 & 1.1 & 1.3 \\
\hline 13 & $\mathrm{~m}^{3} /$ week & 1.4 & 1.4 & 1.6 & 1.6 & 1.5 & 1.5 \\
\hline 14 & $\mathrm{~m}^{3} /$ week & 1.4 & 1.4 & 1.6 & 1.7 & 1.5 & 1.5 \\
\hline 15 & $\mathrm{~m}^{3} /$ week & 1.2 & 1.3 & 1.2 & 1.4 & 1.2 & 1.4 \\
\hline 16 & $\mathrm{~m}^{3} /$ week & 1.6 & 1.6 & 1.9 & 1.9 & 1.7 & 1.8 \\
\hline 17 & $\mathrm{~m}^{3} /$ week & 1.5 & 1.6 & 1.6 & 1.8 & 1.6 & 1.8 \\
\hline 18 & $\mathrm{~m}^{3} /$ week & 1.7 & 1.7 & 1.8 & 2.0 & 1.8 & 1.9 \\
\hline 19 & $\mathrm{~m}^{3} /$ week & 1.6 & 1.7 & 1.7 & 1.9 & 1.6 & 1.8 \\
\hline 20 & $\mathrm{~m}^{3} /$ week & 1.3 & 1.6 & 1.3 & 1.3 & 1.3 & 1.4 \\
\hline 21 & $\mathrm{~m}^{3} /$ week & 1.6 & 1.6 & 1.8 & 1.9 & 1.7 & 1.8 \\
\hline 22 & $\mathrm{~m}^{3} /$ week & 1.5 & 1.5 & 1.7 & 1.8 & 1.6 & 1.7 \\
\hline 23 & $\mathrm{~m}^{3} /$ week & 1.3 & 1.6 & 1.3 & 1.6 & 1.4 & 1.6 \\
\hline 24 & $\mathrm{~m}^{3} /$ week & 1.1 & 1.2 & 1.2 & 1.2 & 1.1 & 1.2 \\
\hline 25 & $\mathrm{~m}^{3} /$ week & 1.2 & 1.2 & 1.2 & 1.2 & 1.2 & 1.3 \\
\hline 26 & $\mathrm{~m}^{3} /$ week & 1.1 & 1.2 & 1.1 & 1.2 & 1.1 & 1.2 \\
\hline 27 & $\mathrm{~m}^{3} /$ week & 1.4 & 1.4 & 1.5 & 1.5 & 1.4 & 1.5 \\
\hline 28 & $\mathrm{~m}^{3} /$ week & 1.5 & 1.5 & 1.7 & 1.7 & 1.6 & 1.6 \\
\hline 29 & $\mathrm{~m}^{3} /$ week & 1.4 & 1.4 & 1.5 & 1.6 & 1.5 & 1.5 \\
\hline 30 & $\mathrm{~m}^{3} /$ week & 1.4 & 1.4 & 1.6 & 1.6 & 1.5 & 1.5 \\
\hline 31 & $\mathrm{~m}^{3} /$ week & 1.2 & 1.3 & 1.3 & 1.4 & 1.3 & 1.3 \\
\hline 32 & $\mathrm{~m}^{3} /$ week & 1.4 & 1.4 & 1.4 & 1.6 & 1.5 & 1.5 \\
\hline 33 & $\mathrm{~m}^{3} /$ week & 1.2 & 1.3 & 1.1 & 1.3 & 1.1 & 1.4 \\
\hline 34 & $\mathrm{~m}^{3} /$ week & 1.3 & 1.5 & 1.3 & 1.4 & 1.3 & 1.4 \\
\hline 35 & $\mathrm{~m}^{3} /$ week & 1.4 & 1.4 & 1.6 & 1.6 & 1.5 & 1.5 \\
\hline 36 & $\mathrm{~m}^{3} /$ week & 1.5 & 1.5 & 1.6 & 1.7 & 1.7 & 1.7 \\
\hline 37 & $\mathrm{~m}^{3} /$ week & 1.4 & 1.5 & 1.5 & 1.6 & 1.4 & 1.6 \\
\hline 38 & $\mathrm{~m}^{3} /$ week & 1.6 & 1.7 & 1.8 & 1.9 & 1.7 & 1.7 \\
\hline 39 & $\mathrm{~m}^{3} /$ week & 1.5 & 1.6 & 1.7 & 1.7 & 1.6 & 1.6 \\
\hline 40 & $\mathrm{~m}^{3} /$ week & 1.6 & 1.6 & 1.9 & 2.0 & 1.8 & 1.8 \\
\hline 41 & $\mathrm{~m}^{3} /$ week & 1.5 & 1.6 & 1.6 & 1.8 & 1.5 & 1.7 \\
\hline 42 & $\mathrm{~m}^{3} /$ week & 1.5 & 1.6 & 1.8 & 1.8 & 1.7 & 1.7 \\
\hline 43 & $\mathrm{~m}^{3} /$ week & 1.3 & 1.5 & 1.4 & 1.6 & 1.4 & 1.5 \\
\hline 44 & $\mathrm{~m}^{3} /$ week & 1.2 & 1.3 & 1.3 & 1.5 & 1.3 & 1.4 \\
\hline 45 & $\mathrm{~m}^{3} /$ week & 1.4 & 1.4 & 1.6 & 1.7 & 1.5 & 1.6 \\
\hline 46 & $\mathrm{~m}^{3} /$ week & 1.3 & 1.4 & 1.3 & 1.5 & 1.3 & 1.5 \\
\hline 47 & $\mathrm{~m}^{3} /$ week & 1.4 & 1.5 & 1.5 & 1.6 & 1.4 & 1.5 \\
\hline 48 & $\mathrm{~m}^{3} /$ week & 1.3 & 1.4 & 1.2 & 1.4 & 1.3 & 1.4 \\
\hline 49 & $\mathrm{~m}^{3} /$ week & 1.2 & 1.4 & 1.3 & 1.4 & 1.2 & 1.3 \\
\hline 50 & $\mathrm{~m}^{3} /$ week & 1.1 & 1.3 & 1.0 & 1.2 & 1.1 & 1.2 \\
\hline 51 & $\mathrm{~m}^{3} /$ week & 0.6 & 0.7 & 0.5 & 0.6 & 0.5 & 0.7 \\
\hline 52 & $\mathrm{~m}^{3} /$ week & 0.5 & 0.7 & 0.5 & 0.6 & 0.5 & 0.6 \\
\hline Total year & $\mathrm{m}^{3} /$ year & 65.6 & 69.5 & 70.6 & 75.3 & 68.7 & 73.1 \\
\hline Costs saved $^{\mathrm{a}}$ & [USD]/year & 49.8 & 52.8 & 53.7 & 57.2 & 52.2 & 55.5 \\
\hline Difference & {$[\mathrm{USD}] /$ year } & 3.0 & & 3.6 & & 3.3 & \\
\hline
\end{tabular}

${ }^{a}$ Estimated based on the water tariff for year 2015 of $0.76 \mathrm{USD} / \mathrm{m}^{3}$ (amb 2015)

( $\left.Q_{\text {pump }}\right)$, which must be greater than the supply flow needed (i.e. determined by the Hunter method for the 
devices where greywater will be reused). The procedure is summarised below (Eqs. 3 and 4),

$t[h]=\frac{\operatorname{vol}\left[\mathrm{m}^{3}\right]}{Q_{\text {pump }}\left[\mathrm{m}^{3} / \mathrm{h}\right]}$

Energy consumption $[\mathrm{kWh}]=P_{\text {pump }}[h p] \times 0.746 \times t[h]$

The operationally derived method outlined in Ward et al. (2011) was not suitable for application in this case due to the system under consideration being hypothetical rather than implemented.

Concerning the parameters for the RWH and GW pumps, the following conditions were established:

- GW pump net positive suction head $\left(\mathrm{NPSH}_{\mathrm{req}} 7.072 \mathrm{~m}\right.$, hydraulic power (hhp) $0.058 \mathrm{hp}$, required power $0.269 \mathrm{hp}$ and nominal power $0.5 \mathrm{hp}$.

- $\quad$ RW pump NPSH req $7.080 \mathrm{~m}$, hhp $0.058 \mathrm{hp}$, required power $0.135 \mathrm{hp}$ and nominal power $0.25 \mathrm{hp}$.

The results obtained by applying Eqs. 3 and 4 are summarised in Table 5. The required power and nominal power of the pumps for GWR and RWH in the three alternatives are presented. Alt 2 had the highest energy consumption (20.6 kW in a year), as in this alternative, a greater amount of water must be pumped. However, this energy consumption was lower compared to that of a conventional fan $(200 \mathrm{~W} / \mathrm{h})$, working $6 \mathrm{~h}$ a day per month ( $432 \mathrm{~kW}$ in a year).

Table 5 Energy consumption for three alternative RWH and GWR system configurations

\begin{tabular}{|c|c|c|c|c|c|}
\hline \multicolumn{2}{|c|}{ Alternative } & \multirow[t]{2}{*}{ Unit } & \multirow{2}{*}{$\frac{\text { Alt } 1}{\text { to, et, it }}$} & \multirow{2}{*}{$\frac{\text { Alt } 2}{\text { snk, wm, et, it }}$} & \multirow{2}{*}{$\begin{array}{l}\text { Alt } 3 \\
\text { snk, wm, i }\end{array}$} \\
\hline RWH & Utilization & & & & \\
\hline & Volume $^{\mathrm{a}}$ & $\mathrm{m}^{3}$ & 65.6 & 70.6 & 68.7 \\
\hline & Flow rate & $\mathrm{L} / \mathrm{s}$ & 0.68 & 0.37 & 0.43 \\
\hline & Required power & HP & 0.31 & 0.13 & 0.16 \\
\hline & Nominal power & HP & 0.50 & 0.25 & 0.25 \\
\hline & Time & $\mathrm{h} /$ year & 27 & 53 & 44 \\
\hline & $\mathrm{kW} /$ year $^{\mathrm{b}}$ & $\mathrm{kW}$ & 10.0 & 9.94 & 8.27 \\
\hline \multirow[t]{7}{*}{ GWR } & Reuse & & - & to & et \\
\hline & Volume $^{\mathrm{a}}$ & $\mathrm{m}^{3}$ & - & 60.72 & 10.37 \\
\hline & Flow rate & $\mathrm{L} / \mathrm{s}$ & - & 0.59 & 0.20 \\
\hline & Required power & HP & - & 0.47 & 0.09 \\
\hline & Nominal power & HP & 0 & 0.50 & 0.25 \\
\hline & Time & $\mathrm{h} /$ year & 0.00 & 29 & 14 \\
\hline & $\mathrm{kW} /$ year $^{\mathrm{b}}$ & $\mathrm{kW}$ & 0 & 10.66 & 2.69 \\
\hline Total & $\mathrm{kW} /$ year $^{\mathrm{b}}$ & & 10.0 & 20.6 & 11.0 \\
\hline
\end{tabular}

to toilet, et external tap, it interior tap, snk sink, $w m$ washing machine

${ }^{\mathrm{a}} \mathrm{m}^{3}$

${ }^{\mathrm{b}} \mathrm{kW}$

\section{Selection of an alternative RWH and GWR configuration}

Table 6 presents a comparison of the three alternative RWH and GWR system configurations against criteria for drinking water and energy savings. In addition to the drinking water and energy savings estimated in the previous sections, Table 6 includes the cost savings associated with reduced drinking water consumption, energy consumption and sewerage reduction based on rates provided by different utility companies (amb 2015 for drinking water; EMPAS 2015 for sewerage and ESSA 2015 for electricity). These were estimated using simple calculations based on the number of units saved multiplied by the value of a unit. After comparing the results for these criteria, Alt 2 was selected as the RWH and GWR systems to assess further due to the greater estimated potential financial savings ( 166.1 USD/year).

\section{Design of RWH and GWR system alternative 2}

To further assess the financial feasibility of the Alt 2 RWH and GWR systems, additional criteria were considered, including the network layout of the different supply systems involved in the overall residential water supply system and the treatment systems required for each source water.

\section{Collection and distribution network}

The full design of Alt 2 considered the different types of networks required in a residential building, which are drinking water (DW), wastewater (WW), collected greywater (CGW),

Table 6 Summary of selection criteria to initially assess three alternative RWH and GWR system designs

\begin{tabular}{llllll}
\hline \multirow{2}{*}{ Criteria } & & Unit & \multicolumn{3}{l}{ Alternative } \\
\cline { 3 - 6 } & & & Alt 1 & Alt 2 & Alt 3 \\
\cline { 3 - 6 } RWH & Drinking water saved & $\mathrm{m}^{3} /$ year & 65.6 & 70.6 & 68.7 \\
& Energy consumption & $\mathrm{kWh} /$ year & 10.0 & 9.9 & 8.3 \\
& Drinking water cost & USD/year & 49.8 & 53.7 & 52.2 \\
& Sewerage cost & USD/year & 31.5 & 33.9 & 33.0 \\
& Energy cost & USD/year & 1.6 & 1.6 & 1.3 \\
GWR & Drinking water saved & $\mathrm{m}^{3} /$ year & - & 60.7 & 10.4 \\
& Energy consumption & $\mathrm{kWh} /$ year & - & 10.6 & 2.7 \\
& Drinking water cost & USD/year & - & 46.1 & 7.9 \\
& Sewerage cost & USD/year & - & 29.2 & 5.0 \\
& Energy cost & USD/year & - & 1.7 & 0.4 \\
\multirow{2}{*}{ Total } & USD & & 82.9 & 166.1 & 99.8 \\
\hline
\end{tabular}

Calculations made with the following rates: water supply $=0.76 \mathrm{USD} / \mathrm{m}^{3}$ $(\mathrm{amb} 2015)$, sewerage $=0.48 \mathrm{USD} / \mathrm{m}^{3}$ (EMPAS 2015) and energy $=0.16$ USD/kWh (ESSA 2015) 
treated greywater (TGW), collected rainwater (CRW) and treated rainwater (TRW). The networks' layout was designed based on concepts from detailed guidelines for domestic water systems (Woolley 2002) and Colombian regulations-NTC 1500 (ICONTEC 2004). Autodesk Revitß software was used, as this enables a workflow-type Building Information Modelling ('BIM') approach that includes the consideration of architectural and structural engineering elements within the designs. In addition, a hydro-pneumatic system design for each of the reuse networks (i.e. TGW and TRW) was included.

The layout and hydraulic networks were designed considering flexibility. Thus, if required, the system could be manually disconnected from the internal distribution network, and all devices could be supplied with drinking water. To enable this, automatic electro-mechanical valves and electric floats, controlled by the end-user or by the tank level, were incorporated.

Within the existing residential building design, the RWH and GWR system's machine room was located below the courtyard garden because of its easy access for maintenance and the possibility of gravity collection of greywater and rainwater without affecting the original architectural design. The disadvantage of this location was the need for excavation and construction of retaining walls in reinforced concrete (Figs. 3 and 4).

\section{Treatment system}

\section{Rainwater}

The RWH system design included a leaf filter and gutter guards to prevent the entry of insects, particulate matter and organic contaminants (OPS 2004). Additionally, it considered a first flush diversion device to improve the quality of the captured water by separating the flow of the first

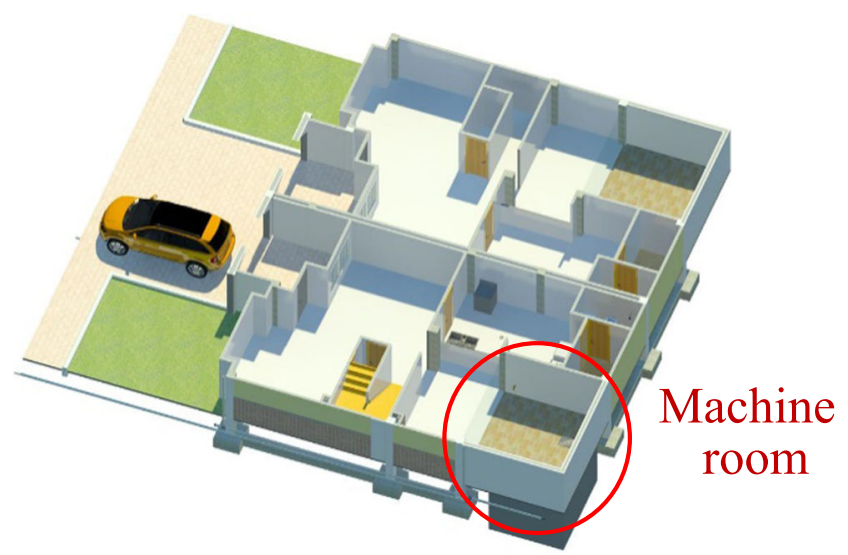

Fig. 3 Machine room location

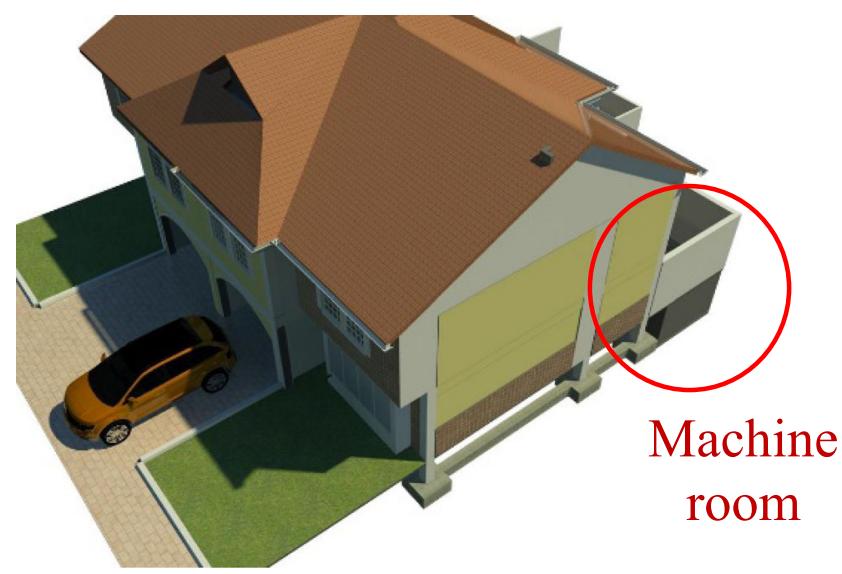

Fig. 4 Exterior 3D view of the machine room location

millimetres of rain, where water is more polluted (Sánchez et al. 2015). Diverting this first flush minimises the physicochemical contamination, but additional components must be included for microbiological treatment (Gikas and Tsihrintzis 2012), and remotion of remaining turbidity, ions (i.e. $\mathrm{Al}, \mathrm{Fe}$ ) and total coliforms, since these elements can generate unwanted odours and water discoloration (Mendez et al. 2011). Additionally, a self-cleaning filter that reduces pollution by heavy metals and improves levels of turbidity and TSS was included. This filter has adjustable treatment capabilities, does not consume energy, maintenance is performed in periods longer than 2 years and it can be built with locally available materials (Vieira et al. 2013).

In general, the described treatment ensures compliance with quality requirements to store and distribute rainwater for non-drinking domestic uses (ARCSA-ASPE 2012; Sanches Fernandes et al. 2015; Texas WDB 2005). However, in cases where there are birds in the area, compliance with microbiological parameters may require disinfection treatment after storage (Lee et al. 2010), such as with a UV device.

\section{Greywater}

Table 7 characterises the levels and treatment technologies usually implemented for GWR.

For the design of the Alt 2 system, the treatment levels considered were preliminary, primary and secondary. The design included the following technological components: grease trap, clarifier tank, slow sand filters and a storage tank. These components are the most commonly used locally and those with lower complexity for the required treatment processes. Figures 5, 6 and 7 detail the networks, the machine room and a summary of the RWH and GWR systems. 
Table 7 Most used greywater treatment technologies

\begin{tabular}{lll}
\hline Type & Remove & Processes \\
\hline Preliminary & Fats, hairs and suspended particles & Solid and fat removal and filtration \\
Primary & Settleables and suspended solids & Sedimentation and filtration \\
Secondary & Biodegradable matter and heavy metals & Filtration, biodegradation and adsorption \\
Tertiary & Nutrients and microbiological agents & Disinfection, nano-filtration and ion exchange \\
\hline
\end{tabular}

Sources: Ghaitidak and Yadav (2013), Merz et al. (2007) and Pidou et al. (2007)

\section{Financial feasibility of the selected alternative}

Fuller consideration of the network layout and treatment processes required by the Alt 2 RWH and GWR systems enabled a more in-depth estimation of the financial feasibility of the implementation of the system within a residential building. This brief section describes the method used to generate costs and the indicators used to assess feasibility. The following section describes the results of applying the method and indicators.

\section{Costs}

The net construction cost was the difference between the total cost of the (conventional) original system and the Alt 2 RWH and GWR systems. The conventional and Alt 2 designs were modelled in Autodesk Revit ${ }^{\circledR}$ to estimate workloads and a budget for the total system cost. Unit prices were obtained from the ConstruData ${ }^{\circledR}$ database (a comprehensive online database of construction costs and other downloadable listings) (ConstruData 2015), as well as price lists suggested by specialised suppliers, including quotations requested by telephone.

Labour-related maintenance costs were estimated from the salary of a qualified technician ( 249 USD/month), according to the Colombian Labour Observatory and the hours needed to carry out the required tasks (i.e. between 2 and $4 \mathrm{~h}$, depending on the type of maintenance).

In the case of electro-mechanical equipment depreciation, the acquisition cost was divided into its lifetime (15 years), according to the equipment providers.

The design cost of Alt 2 considered the price of a typical network design plus an increase for the alternative design (RWH and GWR), which was allocated based on the authors'

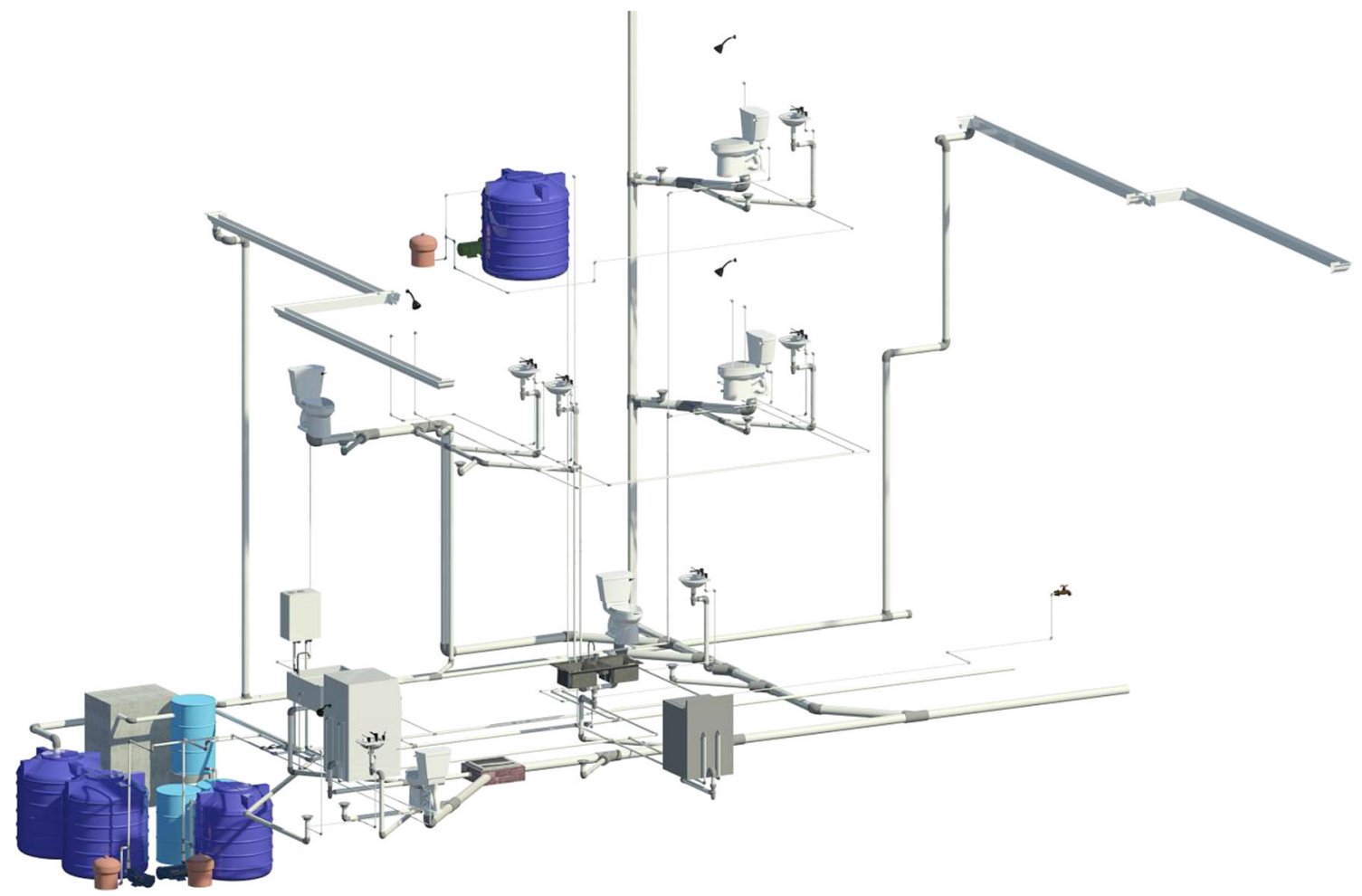

Fig. 5 Proposed RWH and GWR system collection and distribution network design 


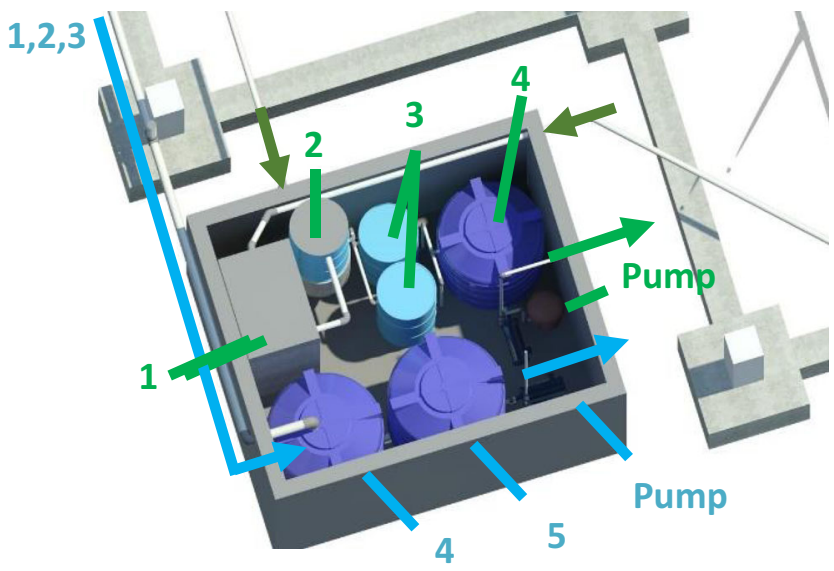

Fig. 6 The 3D view of the RWH and GWR system machine room (numbers correspond to the descriptors in Fig. 7)

experience due to lack of local data on this particular area. All of the derived values and costs are summarised in the "Results and discussion" section.

\section{Feasibility}

To summarise the financial results of the project and thus express its feasibility through a cash flow, the following indicators were used: payback period (PP) (a static measure of investment that allows selecting a project on the basis of how long it will take to recover the initial investment through cash flows), net present value (NPV) (the time value of money as the value of the project and the difference between the cash flow generated on the investment made) and internal rate of return (IRR) (the discount rate that produces a level of the NPV equal to zero). The values for these indicators were estimated based on income, expenses and initial investment. Revenues included savings in the payment of the drinking water and sewerage services. Expenses included equipment maintenance, depreciation and energy costs. The initial investment integrated all processes, materials and supplies needed to install the Alt 2 RWH and GWR systems.
Cash flow was projected for 50 years based on the recommendations in the regulations for life cycle assessment of environmental projects (ISO 14040 2006). Table 8 summarises the basic information for the analysis of financial feasibility.

For all factors, an average inflation of $4.05 \%$, according to the average change over the last 10 years on the consumer price index (CPI) in Colombia, was considered.

To estimate the projected income, an effective annual rate of $6.05 \%$ was considered for the first 23 years (maximum operating point of a reservoir that supplies water during that period to metropolitan Bucaramanga). This value included an inflation of 4.05 and $2.00 \%$ surcharge to finance the current reservoir (amb 2015). After the year 23, a rate of $7.05 \%$ was considered due to a $1.00 \%$ surcharge for future infrastructure construction and $2.00 \%$ due to growth in demand that occurs to the same extent (DNP 2009).

Similarly, the revenue analysis considered that the water shortage in the country would affect energy costs due to the high dependence of the Colombian electrical system on hydro-electric plants. Therefore, a $1 \%$ increase over the baseline increase, for a total $5.05 \%$ discount rate on energy costs, was included.

\section{Results and discussion}

Bringing together all of the Alt 2 RWH and GWR system networks, treatment and cost elements described in the previous sections enabled a cost analysis to be performed, upon which a financial feasibility assessment could then be estimated.

\section{Cost analysis of the Alt 2 RWH and GWR systems}

Table 9 includes a comparison of the construction costs of Alt 2 against the original system, for different budget items. For example, implementing a RWH system slightly increases the rainwater collection cost due to the requirement for additional components to ensure efficient operation. However, this is

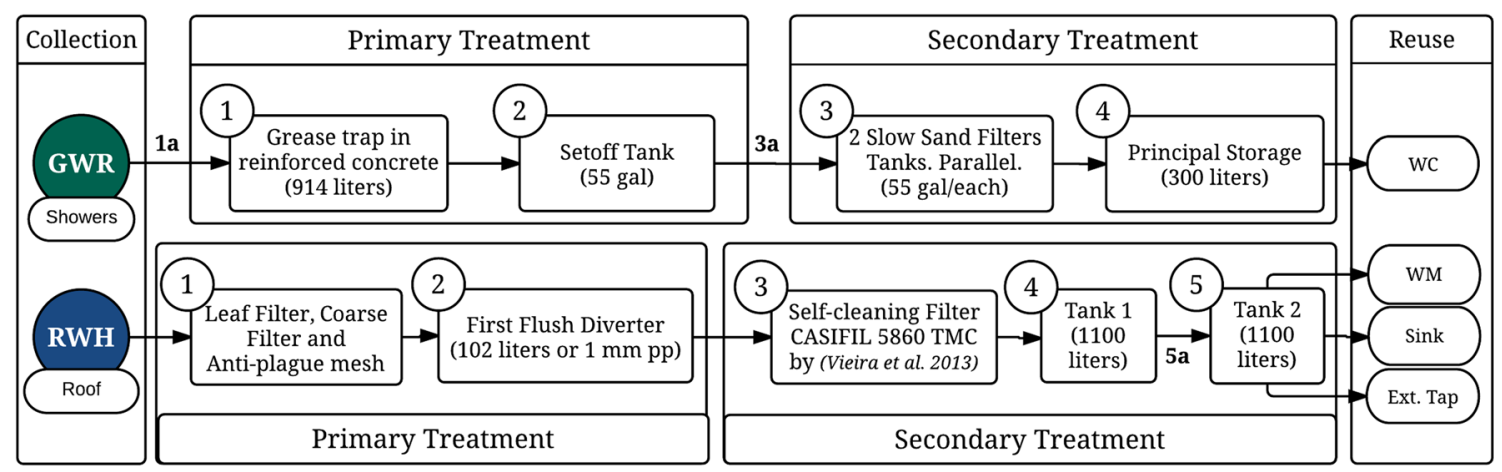

(1a) Coarse filtration (200nm). 3a. Nylon Filter (300nm). 5a. Nylon Filter (300nm). (nm) Nanometers.

Fig. 7 Detailed configuration of the design of the Alt 2 RWH and GWR systems 
Table 8 Summary of Alt 2 RWH and GWR system project information for financial feasibility

\begin{tabular}{lll}
\hline General project data & Unit & Data \\
\hline Water consumption & lpcd & 203 \\
Household size & inhab & 4 \\
Roof area & $\mathrm{m}^{2}$ & 102 \\
RWH storage & $\mathrm{L}$ & 2000 \\
GW storage & $\mathrm{L}$ & 300 \\
Concept & Increment rates \\
Projected inflation in Colombia $(2015)^{\mathrm{a}}$ & $4.05 \%$ & \\
Drinking water cost (until year 22) & $6.05 \%$ & \\
Drinking water cost (from year 23) & $7.05 \%$ & \\
Sewer system cost & \\
Energy cost & $4.05 \%$ & \\
Maintenance ${ }^{\mathrm{b}}$ cost $^{\mathrm{b}}$ & $5.00 \%$ & \\
VPN rate $^{\mathrm{b}}$ & $4.05 \%$ & \\
\hline
\end{tabular}

${ }^{a}$ From National Department of Statistics of Colombia

b From water, sewerage and energy companies' tariffs

offset by the slightly reduced cost associated with sewage aspects due to the reuse of the rainwater within the building.

Table 10 shows the operation and maintenance (O\&M) costs for Alt 2, including the required activities (e.g. cleaning of units, maintenance, electro-mechanic and electronic elements depreciation and replacement of equipment), their unit prices, quantity per year and total annual costs (refer to the "Materials and methods" section).

According to the cost analysis, investment for the Alt 2 system (excluding the value of the house) was 4298 USD.
This value was $63 \%$ higher compared to the original conventional system (i.e. without RWH and GWR). In this increase, the equipment located in the machine room and the design costs were the most representative factors. To put this into perspective, the increase in the cost of the Alt 2 system accounted for $1.6 \%$ of the total cost of the house (i.e. 261,352 USD for 2015). The annual maintenance cost to ensure system operation was 67 USD.

\section{Financial feasibility}

Table 11 presents a summary of the financial projection for 50 years after Alt 2 system installation. According to the financial analysis developed, project implementation can generate a positive net cash flow from the year 23 (payback period). For the 50 years of project operation, a $6.5 \%$ IRR and NPV of 4053 USD were determined.

Most research on RWH and GWR has been developed in building types different to individual households (i.e. public facilities, office buildings, universities and residential complexes) and has mainly been undertaken for RWH or GWR separately. Other studies have identified that the RR is less when systems are implemented in multifamily dwellings compared with individual households (Friedler and Hadari 2006; Morales-Pinzón et al. 2014). However, other experiences (Cardona 2007; Sanches Fernandes et al. 2015) indicate that positive results can be achieved in individual households if the design is effective and treatment devices are available locally, which is consistent with the approach followed in this investigation.
Table 9 Summary of construction costs for the Alt 2 RWH and GWR systems compared to the original (conventional) system

\begin{tabular}{|c|c|c|c|}
\hline \multicolumn{2}{|c|}{ Chapter } & \multirow{2}{*}{$\begin{array}{l}\text { RWH and GWR system } \\
\text { (USD) } \\
382.41\end{array}$} & \multirow{2}{*}{$\begin{array}{l}\begin{array}{l}\text { Original system } \\
\text { (USD) }\end{array} \\
348.86\end{array}$} \\
\hline 1 & Location and setting out on site & & \\
\hline 2 & Sewage & $1,160.33$ & $1,287.64$ \\
\hline 3 & Drinking water & 854.52 & 799.30 \\
\hline 4 & Greywater collection & 223.78 & - \\
\hline 5 & Greywater treatment & 163.33 & - \\
\hline 6 & Rainwater collection & 724.57 & 571.68 \\
\hline 7 & Rainwater treatment & 113.16 & - \\
\hline 8 & $\begin{array}{l}\text { Hydraulic and sanitary connections and } \\
\text { devices }\end{array}$ & $2,974.61$ & $2,939.54$ \\
\hline 9 & Testing and monitoring & 197.36 & 185.63 \\
\hline 10 & Machine room & $2,011.33$ & - \\
\hline \multirow[t]{5}{*}{11} & Hydro-sanitary and treatment design & $1,960.14$ & 653.38 \\
\hline & Total costs [USD] & $10,765.54$ & $6,786.03$ \\
\hline & Additional fees $(8 \%)^{\mathrm{a}}[\mathrm{USD}]$ & 861.24 & 542.88 \\
\hline & Total investment [USD] & $11,626.78$ & $7,328.91$ \\
\hline & System investment [USD] & & $4,297.87$ \\
\hline
\end{tabular}

${ }^{\text {a }}$ Based on authors' judgement due to lack of data 
Table 10 Annual operation and maintenance $(\mathrm{O} \& M)$ costs for the Alt 2 RWH and GWR systems

\begin{tabular}{llll}
\hline Type & $\begin{array}{l}\text { Unit price } \\
\text { (USD) }\end{array}$ & $\begin{array}{l}\text { Quantity } \\
\text { per year }\end{array}$ & $\begin{array}{l}\text { Total price } \\
\text { (USD) }\end{array}$ \\
\hline Rainwater tank cleaning $(2 \times 1100 \mathrm{~L})$ & 6.5 & 0.50 & 3.3 \\
Greywater tank cleaning (500 L) & 3.3 & 1.00 & 3.3 \\
Greywater compensation tank cleaning (500 L) & 3.3 & 1.00 & 3.3 \\
Grease trap cleaning (filter changes included) & 14.7 & 1.00 & 14.7 \\
Slow sand filter cleaning (sand replacement included) & 32.0 & 0.13 & 4.0 \\
Gutter cleaning & 3.3 & 1.00 & 3.3 \\
Electro-mechanic and electronic element depreciation & 16.0 & 1.00 & 16.0 \\
Pumping system preventive maintenance & 5.9 & 2.00 & 11.8 \\
Electronic valve and float preventive maintenance & 39.2 & 2.00 & 7.8 \\
Total/year & & & 67.4 \\
\hline
\end{tabular}

Electro-mechanical equipment includes pumps for rainwater and greywater
In the studies listed in Table 12, indicators of financial feasibility for various RWH and GWR projects and the present case study are shown. The results of PP and IRR from the present investigation have intermediate values compared with the results reported by other studies (PP 11 to 44 years and IRR between 3.7 and 5.7\%). The comparison includes studies in multifamily dwellings.

The implementation of the Alt 2 RWH and GWR systems in this case study was financially feasible, obtaining higher return rates on the investment compared to most studies reviewed (Table 12). In addition, comparing the case study with multifamily buildings or offices, the return time was substantially lower, showing the potential of this alternative. Lee et al. (2016) indicate that one of the challenges to increase RWH in Malaysia is the implementation by governments of subsidies for initial investment. Consequently, financial indicators such as net present value and internal rate of return can demonstrate better performance. This type of incentive, implemented in contexts such as the one proposed in this study, could help to improve financial results such as the internal rate of return.

In addition, the analysis developed in this paper should be complemented by evaluating the externalities of this type of project in the social and environmental dimensions, including aspects such as those suggested by Liang and van Dijk (2010), for example, (i) social awareness towards water availability and protection, (ii) noise pollution, (iii) avoided water pollution, (iv) avoided aquifer overexploitation, (v) chemical and biological risks associated with wastewater reuse and (vi) avoided treatment water costs. Through involvement in the design process, there is potential for increasing the end-user's ownership of and appreciation for the efficacy and financial feasibility of an installation (Ward et al. 2013), and further work is ongoing in this area. Furthermore, to increase the availability of appropriate information to facilitate decision making regarding the implementation of individual or community systems for RWH and GWR, additional studies similar to that proposed by Gurung and Sharma (2014) for RWH may be required in order to compare the financial indicators proposed in the present paper.

Complementary analysis can be developed to determine the amount of potable water displaced and runoff attenuated from entering sewers in an urban area, if a household with a roof area as described in this study captures and uses rainwater. For example, Rostad et al. (2016) show for four major US metropolitan areas (New York City, Philadelphia, Chicago and Seattle) that typical urban RWH configurations, consisting of a $100-\mathrm{m}^{2}$ roof connected to a $5-\mathrm{m}^{3}$ storage volume, would be able to reduce potable water demand by over $65 \%$ in all cities whilst also reducing roof runoff generation by over $75 \%$.

The implementation of alternatives such as the one described in this study involves new approaches to civil and architectural
Table 11 Financial projection for the Alt 2 RWH and GWR systems in a residential building

\begin{tabular}{|c|c|c|c|c|c|c|}
\hline \multirow[t]{2}{*}{ Year } & \multicolumn{2}{|l|}{ Income (USD) } & \multicolumn{2}{|c|}{ Expenses (USD) } & \multirow{2}{*}{$\begin{array}{l}\text { Cash flow } \\
\text { (USD) }\end{array}$} & \multirow{2}{*}{$\begin{array}{l}\text { Net cash flow } \\
\text { accumulated (USD) }\end{array}$} \\
\hline & Drinking water & Sewerage & Energy & Maintenance & & \\
\hline 0 & & & & & $-4,298$ & \\
\hline 1 & 99 & 63 & 3 & 67 & 92 & -4208 \\
\hline 21 & 341 & 145 & 9 & 155 & 322 & -241 \\
\hline 22 & 365 & 151 & 10 & 161 & 345 & 104 \\
\hline 50 & 2,295 & 442 & 37 & 472 & 2,229 & 28,356 \\
\hline
\end{tabular}


Table 12 Profitability analyses of GW and RWH reuse in diverse contexts, including the present study

\begin{tabular}{|c|c|c|c|c|c|c|}
\hline Country $^{\mathrm{a}}$ & Reference & Scale $^{\mathrm{b}}$ & Occupancy & System & Description $^{\mathrm{c}}$ & Results $^{\mathrm{d}}$ \\
\hline $\mathrm{CO}$ & Galvis (2013) & $R$ & $\begin{array}{l}300 \text { households, } 4 \\
\text { inhabitants/house }\end{array}$ & GWR & $\begin{array}{l}T \text { multiple filtration steps, } \\
\text { flocculator }\end{array}$ & $\begin{array}{l}\text { PP } 11 \text { years, } \\
\text { IRR (15) } 5.75 \%\end{array}$ \\
\hline $\mathrm{CO}$ & $\begin{array}{l}\text { Estupiñán et } \\
\text { al. (2011) }\end{array}$ & $U$ & Roofs and courts & RWH & $\begin{array}{l}T \text { filtration, decantation, } \\
\text { activated } \\
\text { carbon, RS } 435 \mathrm{~m}^{3}\end{array}$ & $\begin{array}{l}\text { PP } 22 \text { years, } \\
\text { IRR (33) } 3.7 \%\end{array}$ \\
\hline $\mathrm{BR}$ & $\begin{array}{l}\text { Ghisi and } \\
\text { Oliveira (2007) }\end{array}$ & SH & $\begin{array}{l}\text { One household, three } \\
\text { inhabitants }\end{array}$ & GWR and RWH & $\begin{array}{l}T \text { wetland, RS } 750 \mathrm{~L}, \mathrm{RA} \\
202 \mathrm{~m}^{2} \text {, use to and wm }\end{array}$ & PP 29 years \\
\hline SP & $\begin{array}{l}\text { Morales-Pinzón } \\
\text { et al. (2014) }\end{array}$ & $\mathrm{GH}$ & $\begin{array}{l}\text { Two households, four } \\
\text { inhabitants/house }\end{array}$ & RWH & $\begin{array}{l}T \text { none, RS } 3 \mathrm{~m}^{3} \text {, RA } 80 \mathrm{~m}^{2} \text {, } \\
\text { use wm }\end{array}$ & $\begin{array}{l}\text { PP } 44 \text { years, } \\
\quad \text { IRR }(50)-0.4 \%\end{array}$ \\
\hline SP & $\begin{array}{l}\text { Domènech and } \\
\text { Saurí (2011) }\end{array}$ & GH & $\begin{array}{l}\text { One household, three } \\
\text { inhabitants }\end{array}$ & RWH & $\begin{array}{l}T \text { none, RS } 5 \mathrm{~m}^{3}, \text { RA } 80 \mathrm{~m}^{2} \text {, } \\
\text { use to and wm }\end{array}$ & PP 37 years \\
\hline $\mathrm{EN}$ & Ward et al. (2012) & $O$ & $\begin{array}{l}\text { Occupancy } 300 \\
\text { inhabitants } \\
\text { (actual 111) }\end{array}$ & RWH & $\begin{array}{l}T \text { none, RS } 25 \mathrm{~m}^{3}, \text { RA } 1500 \mathrm{~m}^{2}, \\
\text { use to }\end{array}$ & PP 11 years \\
\hline $\mathrm{CO}$ & This research & $\mathrm{SH}$ & $\begin{array}{l}\text { One house, four } \\
\text { inhabitants }\end{array}$ & GWR and RWH & $\begin{array}{l}T \text { slow filtration; grease trap; } \\
\text { RS } 2 \mathrm{~m}^{3} \text {; RA } 102 \mathrm{~m}^{2} ; \text { use } \\
\text { to, wm, snk, et, it }\end{array}$ & $\begin{array}{l}\text { PP } 23 \text { years, } \\
\text { IRR (50) } 6.50 \%\end{array}$ \\
\hline
\end{tabular}

${ }^{a} C O$ Colombia, $B R$ Brazil, SP Spain, EN England

${ }^{\mathrm{b}} \mathrm{SH}$ single house, $G H$ group of houses, $R$ residential building, $O$ office building, $U$ university

${ }^{\mathrm{c}} T$ treatment system, $R S$ rainwater storage, $R A$ roof area, to toilet, $w m$ washing machine, et external tap, it interior tap, snk sink

${ }^{\mathrm{d}} P P$ payback period, $I R R$ internal rate of return at specified year

designs for this type of household, which requires training of skilled professionals to include these new approaches. In addition, the effects of implementing such approaches on urban rainwater collection should be evaluated as a contribution to address current urban water management challenges.

\section{Conclusions}

This article presented a financial feasibility assessment for RWH and GWR systems ('Alt 2') for a high water consumption household in the metropolitan area of Bucaramanga (Colombia), which utilised questionnaire, construction database, BIM data and several standard financial indicators.

Promising results were estimated for the RWH and GWR systems at the individual household scale, with additional investment costs (over the conventional system) accounting for only $1.6 \%$ of the total cost of the studied household. The estimated payback period of 23 years was lower than reported in other studies for commercial and residential buildings (individual and collective).

The RWH and GWR systems selected and analysed in this study were designed based on consultation with potential endusers, increasing the possibility of its implementation. The opinions of potential end-users were considered in aspects such as willingness to use alternative sources (rainwater and greywater), purpose for the use of alternative sources, willingness to pay for investment and O\&M and willingness to carry out O\&M activities.
The implementation of decentralised RWH and GWR systems and their scaling-up could have positive effects on society and the protection of water resources. These aspects should also be quantified through complementary financial feasibility and cost-benefit assessments to enable better consideration of social (e.g. health and wellbeing) and environmental aspects. Such studies could provide information for formulating public policies that enable the broader appropriate uptake of alternative water sources and supply systems in the context of developing countries such as Colombia.

Acknowledgements The authors thank Universidad Industrial de Santander for the support received whilst writing this paper.

Open Access This article is distributed under the terms of the Creative Commons Attribution 4.0 International License (http:// creativecommons.org/licenses/by/4.0/), which permits unrestricted use, distribution, and reproduction in any medium, provided you give appropriate credit to the original author(s) and the source, provide a link to the Creative Commons license, and indicate if changes were made.

\section{References}

amb - Acueducto Metropolitano de Bucaramanga. (2015) Tarifas Servicio de Acueducto [WWW Document]. URL http://www.amb.com.co/ frmInformacion.aspx?inf=32 (accessed 5.16.15).

Agua2use (2015) Aqua2use greywater reuse [WWW Document]. URL http://www.aqua2use.com/products/gwdd.html (accessed 4.29.15).

Al-Jayyousi OR (2003) Greywater reuse: towards sustainable water management. Desalination 156(1):181-192. doi:10.1016/S00119164(03)00340-0 
ARCSA - ASPE. (2012) Rainwater catchment systems: ARCSA-ASPEANSI 63-2013. Estados Unidos.

BSI. (2013) BS 8515:2013: Rainwater harvesting systems - a code of practice. BSI, London.

Cardona, C. (2007) An integrated approach towards assessing the feasibility of domestic rainwater harvesting in Malta. UNESCO/GWADI Workshop on Water Harvesting, Aleppo.

Cohim, E., Garcia, A., Kiperstok, A., Cunha Dias, M. (2009) Consumo de água em residencias de baixa renda, estudo de caso. In $25^{\circ}$ Congresso Brasileiro de Engenharia Sanitária e Ambiental-ABESAssociação Brasileira de Engenharia Sanitária e Ambiental.

ConstruData (2015). Software, revistas e información especializada para construcción, arquitectura e ingeniería [WWW Document]. URL http://www.construdata.com/ (accessed 4.29.15).

Couto, E. De A. Do Calijuri, M.L., Assemany, P.P., Santiago, A. Da F., Lopes, L.S. (2015) Greywater treatment in airports using anaerobic filter followed by UV disinfection: an efficient and low cost alternative. J. Clean. Prod., Bridges for a more sustainable future: Joining Environmental Management for Sustainable Universities (EMSU) and the European Roundtable for Sustainable Consumption and Production (ERSCP) conferences 106, 372-379. doi:10.1016/j. jclepro.2014.07.065

CRA - Comisión Reguladora de Agua Potable y Saneamiento. (2001) Estimación del consumo básico de agua potable en Colombia. Comisión de Regulación de Agua Potable y Saneamiento Básico, Bogotá D.C.

CRC Australia (2008) Water quality and health risks from urban rainwater tanks, Research Report. Cooperative Research Centre for Water Quality and Treatment, Australia

De Araujo Batista FG, Oliveira D, Dos S, Queiroz F, De RP (2015) Percepcao socioambiental do reuso das águas residuárias em condomínios verticais da cidade da Campina Grande. HOLOS 6: 70-82. doi:10.15628/holos.2014.1406

DNP - Departamento Nacional de Planeación. (2009) Importancia estrategia del "Apoyo financiero para la implementación del proyecto de regulación Embalse de Bucaramanga." República de Colombia

Dobrowksy PH, Mannel D, de Kwaadsteniet M, Prozesky H, Khan W, Cloete TE (2014) Quality assessment and primary uses of harvested rainwater in Kleinmond, South Africa. Water SA 40(3):401-406

Domènech L, Saurí D (2011) A comparative appraisal of the use of rainwater harvesting in single and multi-family buildings of the Metropolitan Area of Barcelona (Spain): social experience, drinking water savings and economic costs. J Clean Prod 19:598-608. doi: 10.1016/j.jclepro.2010.11.010

EMPAS (2015) Tarifas Servicio de Alcantarillado Bucaramanga [WWW Document]. URL http://www.empas.gov.co/informacion.php?id= 46\#empresa (accessed 5.16.15)

ESSA (2015) Tarifas Servicio de Energía Eléctrica Bucaramanga [WWW Document]. URL http://www.essa.com.co/site/

Estupiñán P., Zapata, J.L., HO, G. (2011) Requerimientos de infraestructura para el aprovechamiento sostenible del agua lluvia en el campus de la Pontificia Universidad Javeriana, sede Bogotá. Trabajo de Grado. Ingeniería Civil. Pontificia Universidad Javeriana. p. 172

ETH. (2009) Greywater treatment on household level in developing countries: a state of the art review. https://www.uvm.edu/ ewb/ Documents/Grey\%20Water\%20in\%20Developing\%20Countries. pdf (accessed 20.04.16)

FAO (2014) AQUASTAT database [WWW Document]. Food Agric. Organ. U. N. FAO. URL http://www.fao.org/nr/water/aquastat/ water_use/index.stm (accessed 12.10.14).

Fewkes A, Butler D (2000) Simulating the performance of rainwater collection and reuse systems using behavioural models. Build Serv Eng Res Technol 21(2):99-106
Friedler E (2004) Quality of individual domestic greywater streams and its implication for on-site treatment and reuse possibilities. Environ Technol 25:997-1008

Friedler E, Hadari M (2006) Economic feasibility of on-site greywater reuse in multi-storey buildings. Desalination 190:221-234. doi:10. 1016/j.desal.2005.10.007

Galvis, A. (2013) Viabilidad técnica y económica del aprovechamiento de aguas grises domésticas (masters). Departamento de Ingeniería Química y Ambiental. Fsaculta de ingeniería.ñ Universidad Nacional de Colombia, Bogotá D.C. p. 101.

Gardels, D.J., (2011) Economic input-output life cycle assessment of water reuse strategies in residential buildings and communities [WWW Document]. URL http://digitalcommons.unl.edu/cgi/viewcontent. cgi? article $=1017 \&$ context $=$ civilengdiss $($ accessed 5.9.15).

Ghaitidak DM, Yadav KD (2013) Characteristics and treatment of greywater-a review. Environ Sci Pollut Res 20:2795-2809. doi: 10.1007/s11356-013-1533-0

Ghisi E (2001) Parameters influencing the sizing of rainwater tanks for use in houses. Water Resour Manag 24:2381-2403. doi:10.1007/ s11269-009-9557-4

Ghisi E, Oliveira S (2007) Potential for potable water savings by combining the use of rainwater and greywater in houses in southern Brazil. Build Environ 42:1731-1742. doi:10.1016/j.buildenv.2006.02.001

Gikas GD, Tsihrintzis VA (2012) Assessment of water quality of firstflush roof runoff and harvested rainwater. J Hydrol 466-467:115126. doi:10.1016/j.jhydrol.2012.08.020

Gurung TR, Sharma A (2014) Communal rainwater tank systems design and economies of scale. J Clean Prod 67:26-36. doi:10.1016/j. jclepro.2013.12.020

GWA. (2011) Guidelines for the non-potable uses of recycled water in Western Australia. Australia. 91p.

Hoolohan C, Browne A (2016) Reframing water efficiency: determining collective approaches to change water use in the home. Br J Environ Clim Chang (In Press), currently available at: https://www. academia.edu/8360427/Reframing_intervention_what_does_a_ collective_approach_to_behaviour_change_look_like

Huston R, Chan YC, Chapman H, Gardner T, Shaw G (2012) Source apportionment of heavy metals and ionic contaminants in rainwater tanks in a subtropical urban area in Australia. Water Res 46:11211132. doi:10.1016/j.watres.2011.12.008

ICONTEC (2004) Norma Técnica Colombiana - NTC 1500. Código Colombiano de Fontanería. República de Colombia. 82p.

IDEAM (2015) Precipitation Data: Institute of Hydrology, Meteorology and Environmental Studies (IDEAM) [WWW Document]. Precip. Data Hydrol. Stn. URLhttp://www.ideam.gov.co/web/tiempo-yclima/precipitacion-en-el-contexto-historico

ISO- International Organization for Standardization. 14040 (2006). Environmental management-life cycle assessment-principles and framework. International

Kujawa K, Zeeman G (2006) Anaerobic treatment in decentralised and source-separation-based sanitation concepts. Rev Environ Sci Biotechnol 5:115-139. doi:10.1007/s11157-005-5789-9

Kwaadsteniet M, Dobrowsky P, Deventer A, Khan W, Cloete T (2013) Domestic rainwater harvesting: microbial and chemical water quality and point-of-use treatment systems. Water Air Soil Pollut 224:1

Lee JY, Yang J-S, Han M, Choi J (2010) Comparison of the microbiological and chemical characterization of harvested rainwater and reservoir water as alternative water resources. Sci Total Environ 408:896-905. doi:10.1016/j.scitotenv.2009.11.001

Lee JY, Bak G, Han M (2012) Quality of roof-harvested rainwatercomparison of different roofing materials. Environ Pollut 162: 422-429. doi:10.1016/j.envpol.2011.12.005

Lee KE, Mokhtar M, Hanafiah MM, Halim AA, Badusah J (2016) Rainwater harvesting as an alternative water resource in Malaysia: potential, policies and development. J Clean Prod 126:218-222. doi: 10.1016/j.jclepro.2016.03.060 
Li F, Wichmann K, Otterpohl R (2009) Evaluation of appropriate technologies for grey water treatments and reuses. Water Sci Technol 59: 249-260

Liang X, van Dijk MP (2010) Financial and economic feasibility of decentralized wastewater reuse systems in Beijing. Water Sci Technol 61(8):1965-1973

March JG, Gual M (2009) Studies on chlorination of greywater. Desalination 249:317-322. doi:10.1016/j.desal.2009.09.005

Matos C, Pereira S, Amorim EV, Bentes I, Briga-Sá A (2014) Wastewater and greywater reuse on irrigation in centralized and decentralized systems - an integrated approach on water quality, energy consumption and $\mathrm{CO}_{2}$ emissions. Sci Total Environ 493:463-471. doi:10. 1016/j.scitotenv.2014.05.129

Mayer, P.W., DeOreo, W.B., Opitz, E.M., Kiefer, J.C., Davis, W.Y., Dziegielewski, B., Nelson, J.O., (1999) Residential end uses of water. American Water Works Association. $310 \mathrm{pp}$

Melville-Shreeve P, Ward S, Butler D (2016) Rainwater harvesting typologies for UK houses: a multi criteria analysis of system configurations. Water 8:129. doi:10.3390/w8040129

Mendez CB, Klenzendorf JB, Afshar BR, Simmons MT, Barrett ME, Kinney KA, Kirisits MJ (2011) The effect of roofing material on the quality of harvested rainwater. Water Res 45:2049-2059. doi:10. 1016/j.watres.2010.12.015

Merz C, Scheumann R, El Hamouri B, Kraume M (2007) Membrane bioreactor technology for the treatment of greywater from a sports and leisure club. Desalination 215:37-43. doi:10.1016/j.desal.2006.10.026

Morales-Pinzón T, Lurueña R, Gabarrell X, Gasol CM, Rieradevall J (2014) Financial and environmental modelling of water hardness - implications for utilising harvested rainwater in washing machines. Sci Total Environ 470-471:1257-1271. doi:10.1016/j. scitotenv.2013.10.101

Motawa I, Carter K (2013) Sustainable BIM-based evaluation of buildings. Procedia - Soc Behav Sci 74:419-428. doi:10.1016/j.sbspro. 2013.03.015

Mourad KA, Berndtsson JC, Berndtsson R (2011) Potential fresh water saving using greywater in toilet flushing in Syria. J Environ Manage 92:2447-2453

Muthukumaran S, Baskaran K, Sexton N (2011) Quantification of potable water savings by residential water conservation and reuse- - a case study. Resour Conserv Recycl 55:945-952. doi:10.1016/j. resconrec.2011.04.013

Neto RFM, Calijuri ML, Carvalho I, De C, Santiago A, Da F (2012) Rainwater treatment in airports using slow sand filtration followed by chlorination: efficiency and costs. Resour Conserv Recycl 65: 124-129. doi:10.1016/j.resconrec.2012.06.001

OPS. Organización Panamericana de la Salud (2004) Guía de diseño de Captación del agua lluvia. UNATSABAR, Lima, Perú.

Peters AJ, Weidner KL, Howley CL (2008) The chemical water quality in roof-harvested water cisterns in Bermuda. J Water Suppl Res Technol-AQUA 57:153-163. doi:10.2166/aqua.2008.045

Pidou M, Memon FA, Stephenson T, Jefferson B, Jeffrey P (2007) Greywater recycling: a review of treatment options and applications. Inst Civ Eng 160:119-131

Prathapar SA, Jamrah A, Ahmed M, Al Adawi S, Al Sidairi S, Al Harassi A (2005) Overcoming constraints in treated greywater reuse in Oman. Desalination 186(1):177-186

Robson, C. (2002) Real world research: a resource for social scientists and practitioner-researchers. John Wiley \& Sons.

Roebuck A (2007) Predicting the hydraulic and life-cycle cost performance of rainwater harvesting systems using a computer based modelling tool. Water Pract Technol. doi:10.2166/wpt.2007.046

Rostad N, Foti R, Montalto FA (2016) Harvesting rooftop runoff to flush toilets: Drawing conclusions from four major US cities. Resour Conserv Recycl 108:97-106. doi:10.1016/j. resconrec.2016.01.009
Sahin O, Stewart RA, Porter MG (2015) Water security through scarcity pricing and reverse osmosis: a system dynamics approach. J Clean Prod 88:160-171. doi:10.1016/j.jclepro.2014.05.009

Sanches Fernandes LF, Terencio DPS, Pacheco FAL (2015) Rainwater harvesting systems for low demanding applications. Sci Total Environ 529:91-100. doi:10.1016/j.scitotenv.2015.05.061

Sánchez AS, Cohim E, Kalid RA (2015) A review on physicochemical and microbiological contamination of roof-harvested rainwater in urban areas. Sustain Water Qual Ecol. doi:10.1016/j.swaqe.2015.04.002

Santos C, Taveira-Pinto F (2013) Analysis of different criteria to size rainwater storage tanks using detailed methods. Resour Conserv Recycl 71:1-6. doi:10.1016/j.resconrec.2012.11.004

Sazakli E, Alexopoulos A, Leotsinidis M (2007) Rainwater harvesting, quality assessment and utilization in Kefalonia Island, Greece. Water Res 41:2039-2047. doi:10.1016/j.watres.2007.01.037

Seifert R (2009) Análisis de la situación del agua (cantidad y residual) en Lima Metropolitana. Proyecto LiWa/Zirn-SEDAPAL, Lima

Silva CM, Sousa V, Carvalho NV (2015) Evaluation of rainwater harvesting in Portugal: application to single-family residences. Resour Conserv Recycl 94:21-34. doi:10.1016/j.resconrec.2014.11.004

Stec A, Kordana S (2015) Analysis of profitability of rainwater harvesting, gray water recycling and drain water heat recovery systems. Resour Conserv Recycl 105(Part A):84-94. doi:10.1016/j. resconrec.2015.10.

Suárez, J.A.B., García, M.Á.G., Mosquera, R.O.O. (2006) Sistemas de aprovechamiento de agua lluvia para vivienda urbana. VI sereaseminario iberoamericano sobre sistemas de abastecimiento urbano de agua (brasil).

Texas WDB (2005) The Texas manual on rain water harvesting, 3rd edn. Texas Water Development Board, Austin

Tian Z, Cao G, Shi J, McCallum I, Cui L, Fan D, Li X (2012) Urban transformation of a metropolis and its environmental impacts: a case study in Shanghai. Environ Sci Pollut Res 19:1364-1374. doi:10. 1007/s11356-011-0641-y

UNATSABAR (2001) Guia de diseño para captación del agua lluvia [WWW Document]. Unidad Apoyo Téc. En Saneam. Básico Rural. URL http://www.aguasinfronteras.org/PDF/AGUA\% 20DE\%20LLUVIA.pdf (accessed 4.23.15).

USEPA (2009) National primary and secondary drinking water regulations. United States Environmental Protection Agency, Estados Unidos

Vieira AS, Weeber M, Ghisi E (2013) Self-cleaning filtration: a novel concept for rainwater harvesting systems. Resour Conserv Recycl 78:67-73. doi:10.1016/j.resconrec.2013.06.008

Vieira P, Jorge C, Covas D (2015) Novel performance assessment indices for domestic water use. Procedia Eng 119:813-819. doi:10.1016/j. proeng.2015.08.943

Ward S, Memon FA, Butler D (2010) Harvested rainwater quality: the importance of appropriate design. Water Sci Technol 61: 1707-1714

Ward S, Butler D, Memon FA (2011) Benchmarking energy consumption and $\mathrm{CO}_{2}$ emissions from rainwater-harvesting systems: an improved method by proxy. Water Environ J 26:184-190. doi:10.1111/j.17476593.2011.00279.x

Ward S, Memon FA, Butler D (2012) Performance of a large building rainwater harvesting system. Water Res 46:5127-5134. doi:10. 1016/j.watres.2012.06.043

Ward S, Barr S, Memon F, Butler D (2013) Rainwater harvesting in the UK: exploring water-user perceptions. Urban Water J 10(2):112126. doi:10.1080/1573062X.2012.709256

WHO - ROEM (2006) Overview of greywater management: health considerations. World Health Organization-Regional Office for the Eastern Mediterranean

Woolley, L. (2002) Sanitation details. Routledge. International Thomson Publishing Ltd. 